\title{
Back to the Eneolithic: Exploring the Rudki-type ornaments from Poland
}

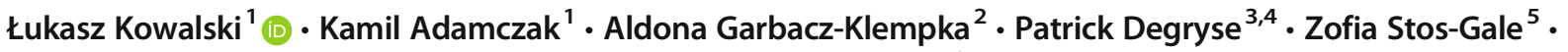 \\ Magdalena Kozicka ${ }^{1} \cdot$ Wojciech Chudziak ${ }^{1} \cdot$ Andrzej Krzyszowski $^{6} \cdot$ Artur Jedynak $^{7}$
}

Received: 15 December 2018 / Accepted: 11 March 2019 /Published online: 13 April 2019

(C) The Author(s) 2019

\begin{abstract}
For a long time, the Eneolithic attribution of the Rudki-type double spiral ornaments was contested by a wide academic audience, and therefore, this new and extraordinary category of the copper metalwork seemed to have fallen into scientific oblivion. In this paper, we contribute to the debate about cultural attribution of the Rudki-type double spiral ornaments considering their chemical and isotope characteristics (using ED XRF and MC-ICP-MS) and the manufacturing technology (OM, X-ray, CT). Noticeably, this study represents the first documented implementation of the lead isotope analysis (LIA) for the Eneolithic metalwork from Poland. The new scientific analyses give ground to the hypothesis that the Rudki-type double spiral ornaments were produced by the Baden culture metalworker(s) who practiced somewhere in the Carpathian Basin and who have used copper ore mined in the Slovak Ore Mountains (Špania Dolina-Banská Bystrica-Kremnica mine complex). These ornaments were redistributed towards the northern ecumene of the Baden culture complex. The new owners, the Funnel Beaker (TRB) culture communities from the region of modern Poland, deposited the ornaments in hoards (Kałdus, Przeuszyn and Rudki) during the mid-4th millennium BC. The results, furthermore, indicate that the so-called Baden spiral metalwork package must be now complemented by the Rudki-type double spiral ornaments. Remarkably, this package also found an echo in pottery decoration, as documented by a narrative scene incised on an amphora from Kałdus, which could be also interpreted as one of the earliest known proofs for the wagon transport in Europe, alongside the famous ones reported from Bronocice or Flintbek.
\end{abstract}

Keywords Eneolithic $\cdot$ TRB $\cdot$ Baden $\cdot$ Spiral metalwork · Wagon · Archaeometallurgy · LIA

Łukasz Kowalski

lukasz.k@doktorant.umk.pl

Kamil Adamczak

adamczak@umk.pl

Aldona Garbacz-Klempka

agarbacz@agh.edu.pl

Patrick Degryse

patrick.degryse@ees.kuleuven.be

Zofia Stos-Gale

zofia@stos-gale.com

Magdalena Kozicka

mkozicka@doktorant.umk.pl

Wojciech Chudziak

wojchud@umk.pl

Andrzej Krzyszowski

andrzej.krzyszowski@muzarp.poznan.pl
Artur Jedynak

artur.archeo@krzemionki.info

1 Institute of Archaeology, Nicolaus Copernicus University in Toruń, Szosa Bydgoska 44/48, 87-100 Toruń, Poland

2 Faculty of Foundry Engineering, Historical Layers Research Centre, AGH University of Science and Technology, Reymonta 23, 30-059 Kraków, Poland

3 Earth and Environmental Sciences, Centre for Archaeological Sciences, KU Leuven, Celestijnenlaan 200E, b2408, 3001 Leuven, Belgium

4 Faculty of Archaeology Material Culture Studies Group, Leiden University, Leiden, The Netherlands

5 Ifold, UK

6 Archaeological Museum in Poznań, Wodna 27 - Pałac Górków, 61-781 Poznań, Poland

7 Archaeological Museum and Reserve "Krzemionki", Sudół 135a, 27-400 Ostrowiec Świętokrzyski, Poland 


\section{Introduction}

A new and extraordinary category of the copper metalwork, displaying a somewhat archaic technological pattern, appeared in a cultural landscape occupied by the communities of the Funnel Beaker (further: TRB) culture during the mid-4th millennium BC in the region of modern Poland (Fig. 1). Arranged in the form of two flat spirals joined in a tight cylindrical link at the centre, the Rudki-type double spiral ornaments (DSO) emerge as a phenomenon of the metalworking praxis shared by the communities of the Baden culture complex (Fig. 1).

In terms of the proposal made by Gedl (2004, pp. 159-61, Taf. 69), such a category of metalwork may be defined as the Doppelspiralscheiben mit Spiraligem Verbindungstück. Although Gedl has himself acknowledged that the ornaments from Przeuszyn and Rudki belong to the Eneolithic, it is clear now that the typological indicators proposed by Gedl were far too general. This overgeneralisation of the typology of double spiral ornaments led to a strong conviction about their nonEneolithic chronology. This assumption was strengthened further by the fact that many very similar objects were made in the Late Bronze Age (further: LBA) and Early Iron Age (further: EIA) (see, e.g. Gedl 2004, p. 161 with further references therein; Seger 1907, p. 33, Fig. 48; Truhelka 1895, p. 510, Fig. 1) (Fig. 2). This is particularly true for the DSOs discovered in Poland, most of which are the legacy of the Lusatian culture (Adamczak et al. 2015a, p. 205; Gedl 2004, pp. 159-61, Taf. 69; Suchy et al. 2016, p. 158).

It is important to stress that the Rudki-type DSOs have not so far been reported from any pan-European Eneolithic ecumene other than those occupied by the TRB communities in the region of modern Poland (Adamczak et al. 2015a, p. 215). When discussing the current state of knowledge about the TRB metalworking praxis, the absence of any conclusive evidence supporting the introduction of copper processing by the local Eneolithic communities from the Vistula and Oder Basins is of great importance (see, e.g. Kowalski et al. 2016, p. 196).

\section{Archaeological background}

At the time of writing, eight double spiral ornaments have been reported from Poland (Fig. 3 and Table 1). They come from the hoards deposited in the areas of intensive TRB settlements. Two DSOs were found in Kałdus and three in Przeuszyn, and finally, three DSOs were discovered in Rudki (Adamczak et al. 2015a; Gedl 2004, p. 160; Kasiński 1936; Koehler 1900, p. 10, Fig. XXV; Kostrzewski 1924, p. 164; 1953, p. 179; 1962, p. 56; Lissauer 1891, p. 75; Schwartz 1881, p. 2; Szpunar 1987, pp. 16-9).

The research results presented here for the Eneolithic hoards from Kałdus have contributed to the issue of a chronological placement of the Rudki-type DSO. The obtained radiocarbon results are consistent and indicate a 3502/3498-3363/ $3356 \mathrm{cal}$ BC date range (see Table 1). Therefore, it allowed us to assign the DSOs deposited in Kałdus with the TRB-MES III phase $(=3500-3350 \mathrm{cal} \mathrm{BC})$ which corresponds with the Boleráz period (Adamczak et al. 2015a, p. 203; Müller 2012, p. 54, Abb. 8; Müller et al. 2012). The copper flat axes of Bytyń type accompanying the DSOs from Przeuszyn and

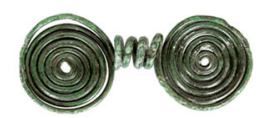

DSO_1

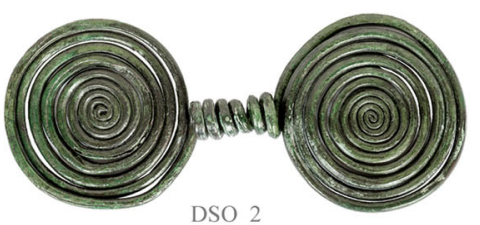

$0-5$

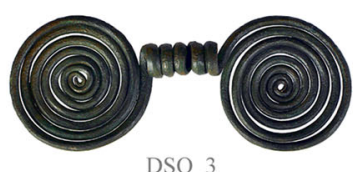

DSO 3

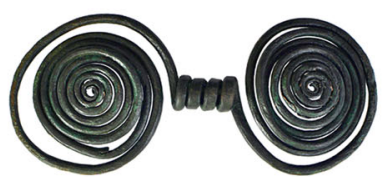

DSO 4

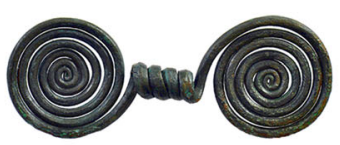

DSO_5
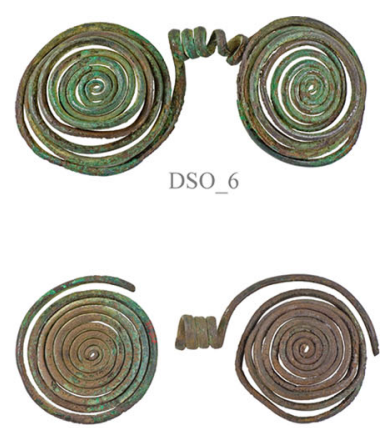

DSO_ 7
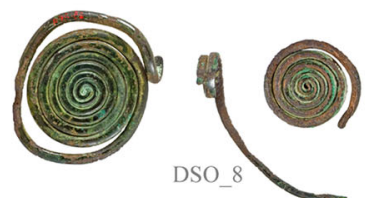

\section{KAEDUS}

Fig. 1 The Rudki-type double spiral ornaments from Poland. The ornaments belong to the hoards which are stored in the Institute of Archaeology, NCU in Torun (Poland; Kałdus), Archaeological Museum
PRZEUSZYN

RUDKI

and Reserve "Krzemionki" Ostrowiec Świętokrzyski (Poland; Przeuszyn) and Archaeological Museum in Poznań (Poland; Rudki) 


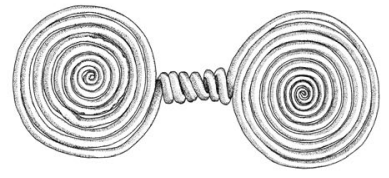

Kałdus (Poland)

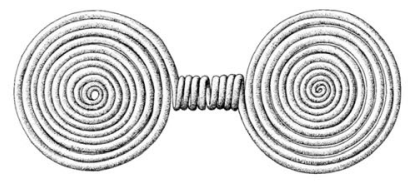

Karmin (Poland)

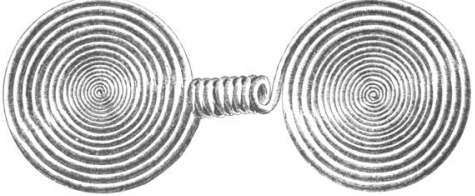

Prozor (Bosnia and Herzegovina)
Fig. 2 The comparison of the double spiral ornaments linked to the Metal Age horizons (Gedl 2004, 160, Taf. 69: A6; Seger 1907, 33, Fig. 48; Truhelka 1895,510 , Fig. 1 , adapted). There is a strong conviction about

Rudki are chronologically placed in the classical and late Wiórek phases of the TRB East Group and, thus, correspond to the Boleráz and classical Baden periods. For that reason, the DSOs from Przeuszyn and Rudki can arbitrarily be placed between 3650 and $3100 \mathrm{cal} \mathrm{BC}$ (Adamczak et al. 2017, pp. 89-90; Łęczycki 2004, p. 70; Müller 2012, p. 54, Abb. 8; Müller et al. 2012; Szpunar 1987, p. 17).

\section{Materials and methods}

The main goal of this work was to deal with certain concerns about the cultural attribution and the chronological placement of the Rudki-type DSOs from Poland. For this purpose, the ornaments were examined in a thorough and comprehensive chronological consistency (non-Eneolithic) of the double spiral ornaments due to the fact that the Late Bronze Age and the Early Iron Age saw many objects fashioned in such a manner

manner. A particular aim of the analyses was to establish the origin of copper metal and the manufacturing technology of these artefacts. Therefore, the spiral ornaments were analysed for their elemental compositions using ED XRF and lead isotope analyses were made using MC-ICP-MC. The results of the analyses provided ground for the construction of an archaeological model proposing the distribution channels and cultural status of the discussed ornaments. Also, the absolute chronological placement of the Rudki-type DSO was taken into consideration in this research project.

\section{Analyses of chemical compositions: ED XRF}

The chemical compositions of the analysed objects were established by means of the energy-dispersive X-ray

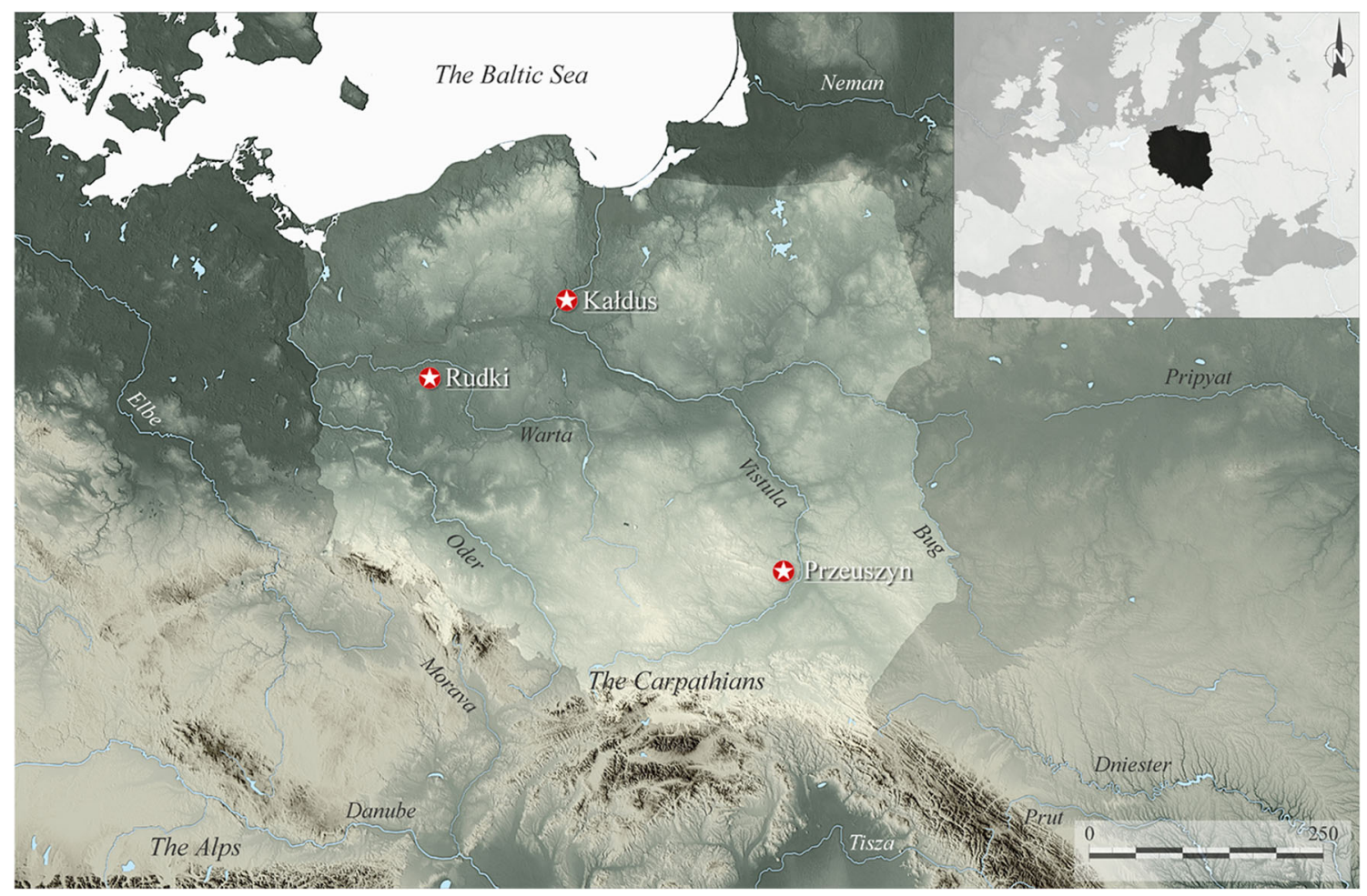

Fig. 3 The distribution of the Rudki-type double spiral ornaments in the region of modern Poland (Adamczak et al. 2015a; Kostrzewski 1962; map background: Yarr65/Shutterstock.com). The ornaments come from the hoards deposited in the areas of dense TRB settlements. The Rudki- type DSOs have not so far been reported from any other European Eneolithic ecumene other than those occupied by the TRB communities in this region 
Table 1 The structure of the hoards with the Rudki-type double spiral ornaments from Poland. The structure of the hoards shows that the ornaments were included with other copper metalwork. The hoards from Przeuszyn and Rudki were arbitrarily placed in between 3650 and $3100 \mathrm{BC}$ due to the chronology of the accompanying copper flat axes

\begin{tabular}{|c|c|c|c|c|}
\hline Signature & Site & Accompanying findings & Chronology $^{\mathrm{a}}$ & References \\
\hline DSO_1 & $\begin{array}{l}\text { Kałdus, Chełmno dist., } \\
\text { feature no. } 470\end{array}$ & $\begin{array}{l}2 \text { ceramic vessels, polishing stone, } \\
\text { animal bones }{ }^{\mathrm{b}} \text {, potsherds }\end{array}$ & $\begin{array}{l}3498-3356 \mathrm{cal} \mathrm{BC} \\
3502-3363 \mathrm{cal} \mathrm{BC}\end{array}$ & Adamczak et al. (2015a, pp. 205-6) \\
\hline DSO_2 & $\begin{array}{l}\text { Kałdus, Chełmno dist., } \\
\text { feature no. } 1186\end{array}$ & $\begin{array}{l}\text { Copper hammer-axe, arsenical bronze } \\
\text { dagger, bone awl }{ }^{\mathrm{b}} \text {, amber disc, clay } \\
\text { spindle whorl, flint retouched blade, } \\
2 \text { flint arrowheads, potsherds }\end{array}$ & $3502-3363 \mathrm{cal} \mathrm{BC}$ & Adamczak et al. (2015a) \\
\hline $\begin{array}{l}\mathrm{DSO}_{-} 3 \\
\mathrm{DSO}_{-} 4 \\
\mathrm{DSO} 5\end{array}$ & $\begin{array}{l}\text { Przeuszyn, Ostrowiec } \\
\text { Świętokrzyski dist. }\end{array}$ & 2 or more flat copper axes & $3650-3100 \mathrm{BC}$ & $\begin{array}{l}\text { Gedl (2004, p. 160), Kasiński (1936), } \\
\text { Kostrzewski (1962, p. 56), } \\
\text { Szpunar (1987, p. 19) }\end{array}$ \\
\hline $\begin{array}{l}\text { DSO_6 } \\
\mathrm{DSO}_{-} 7 \\
\mathrm{DSO}_{-} 8\end{array}$ & Rudki, Szamotuły dist. & $\begin{array}{l}3 \text { flat copper axes, } 6 \text { spiral copper } \\
\text { armbands, silver band ornament, } \\
\text { ceramic vessel }\end{array}$ & $3650-3100 \mathrm{BC}$ & $\begin{array}{l}\text { Gedl (2004, p. 160), Koehler (1900, } \\
\text { p. 10, Fig. XXV), Kostrzewski } \\
\text { (1924, p. 164; 1953, p. 179; 1962, } \\
\text { p. 56), Lissauer (1891, p. 75), } \\
\text { Schwartz (1881, p. 2), } \\
\text { Szpunar (1987, p. 16) }\end{array}$ \\
\hline
\end{tabular}

${ }^{\mathrm{a}}$ The calibrated dates are given as the ranges with $68.2 \%$ probability. A detailed procedure for modelling of the ${ }^{14} \mathrm{C}$ dates obtained for the $R u d k i$-type double spiral ornaments from Kałdus (Poland) is given in the "Chronological placement" section and Table 5

${ }^{\mathrm{b}}$ The ${ }^{14} \mathrm{C}$ sampled material. The dates obtained for the DSO_1 were from two different animal bone samples

fluorescence (ED XRF) in the Laboratory of Historical Layers Research Centre at AGH University of Science and Technology (Poland) using a Spectro Midex spectrometer equipped with a molybdenum X-ray tube and a Si Drift Detector (SDD) with $150 \mathrm{eV}$ resolution at $5.9 \mathrm{keV}$. The analytical conditions used were $44.6 \mathrm{kV}, 5.9 \mathrm{~mA}$ and $180 \mathrm{~s}$ of live time. The ED XRF quantifications were performed with the use of the fundamental parameters program $\mathrm{FP}+$ for the elemental analysis of the alloys. The errors resulting purely from $\mathrm{X}$-ray tube spectral distribution can be significant and exceed even above $10 \%$ relative, and the accuracy of fundamental parameter methods is hampered when undetectable low-Z elements (e.g. C, O) are present in the sample (Sitko 2007, p. 786; Sitko and Zawisza 2012, pp. 144-5; see De Boer et al. (1993), Elam et al. (2004), Mantler and Kawahara (2004) and Sitko $(2007,2008))$.

Surfaces of the analysed artefacts were prepared by mechanical removal of the corrosion products (exposing the metallic core) and followed by degreasing with $\mathrm{O}=\mathrm{C}\left(\mathrm{CH}_{3}\right)_{2}$ (acetone). The chemical compositions of the artefacts were determined on the basis of a series of 5 measurements taken from the metallic core. The analytical error of ED XRF for trace elements in copper is usually below 10\% (Lutz and Pernicka 1996), and the detection limits for each element are given in Table 2. The ED XRF data are listed in Table 2 and plotted on Fig. 8.

\section{Lead isotope analyses: MC ICP MS}

Five samples were collected from Kałdus (DSO_1 and 2) and Przeuszyn (DSO_3, 4 and 5) ornaments. The samples were first weighed in Savillex beakers, after which $2.5 \mathrm{ml} \mathrm{HNO}_{3}$ was added. The beakers were then covered with screw caps and kept closed on a hot plate at $90{ }^{\circ} \mathrm{C}$ overnight. The next day, the closed Savillex beakers were heated for $40 \mathrm{~min}$ at $140{ }^{\circ} \mathrm{C}$. Then the beakers were opened and the temperature increased to $200{ }^{\circ} \mathrm{C}$, until the liquid was evaporated to one large drop; $2 \mathrm{ml}$ $\mathrm{HClO}_{4}$ was added and the beakers were closed again and heated for $1 \mathrm{~h}$ at $200^{\circ} \mathrm{C}$. After $1 \mathrm{~h}$, the caps were removed to let the liquid evaporate at $240{ }^{\circ} \mathrm{C}$. The beakers were swirled occasionally during this process. When only a large drop remained, the beakers were taken from the hot plate and $3 \mathrm{ml} \mathrm{HF}$ was added after cooling. The beakers were placed on the hot plate again without caps to evaporate the liquid until near dryness. Then $2.5 \mathrm{ml}$ of $2.5 \mathrm{M} \mathrm{HCl}$ was added and the beakers were closed to warm up for ca. 10 min to obtain a clear solution. This was again evaporated on a hot plate at $110{ }^{\circ} \mathrm{C}$ until near dryness, after which $5 \mathrm{ml} 1 \mathrm{M} \mathrm{HNO}_{3}$ was added to obtain a clear solution. This solution was used for lead isolation and isotopic analysis by MC-ICP-MS (multi-collector inductively coupledplasma mass spectrometry). Lead isolation (procedure described by De Muynck et al. 2008) was carried out at a class 10 clean lab at Ghent University (Belgium). Pb concentrations of the solutions were determined using a Thermo Scientific Element XR sector field ICP-MS instrument (Ghent University), to calculate dilutions for MC-ICP-MS measurements; $30 \mu \mathrm{g} / 1 \mathrm{Tl}$ (NIST SRM 997) was added as an internal standard to both standards and samples for mass bias correction calculations (see, e.g. Ketterer et al. 1991; Walder et al. 1993). $\mathrm{Pb}$ isotope ratios were determined using a Thermo Scientific Neptune MC-ICP-MS (see De Muynck et al. (2008) for 
Table 2 Results of the ED XRF analyses of the Rudki-type double spiral ornaments from Poland presented as mean values of 5 measurements. 'Imp.' is a total sum of the impurities. Numbers in italics indicate results at, or below detection limits

\begin{tabular}{|c|c|c|c|c|c|c|c|c|c|c|c|}
\hline Signature & Site & $\mathrm{Fe}$ & $\mathrm{Co}$ & $\mathrm{Ni}$ & $\mathrm{Cu}$ & As & $\mathrm{Ag}$ & $\mathrm{Sb}$ & $\mathrm{Pb}$ & $\mathrm{Bi}$ & Imp. \\
\hline DSO_1 & \multirow[t]{2}{*}{ Kałdus, Chełmno dist. } & 0.02 & 0.05 & 0.08 & 99 & 0.25 & 0.03 & 0.03 & 0.15 & 0.01 & 0.56 \\
\hline DSO_2 & & 0.04 & 0.05 & 0.08 & 98 & 1.3 & 0.01 & 0.02 & 0.24 & 0.05 & 1.7 \\
\hline DSO_3 & \multirow[t]{3}{*}{ Przeuszyn, Ostrowiec Świętokrzyski dist. } & 0.02 & 0.05 & 0.07 & 99 & 1.2 & 0.03 & 0.01 & 0.08 & 0.02 & 1.4 \\
\hline DSO_4 & & 0.03 & 0.05 & 0.07 & 99 & 1.1 & 0.02 & 0.03 & 0.02 & 0.01 & 1.2 \\
\hline DSO_5 & & 0.03 & 0.05 & 0.08 & 99 & 0.53 & 0.01 & 0.02 & 0.02 & 0.01 & 0.69 \\
\hline DSO_6 & \multirow[t]{4}{*}{ Rudki, Szamotuły dist. } & 0.02 & 0.05 & 0.09 & 99 & 1.2 & 0.02 & 0.02 & 0.07 & 0.03 & 1.4 \\
\hline DSO_7 & & 0.02 & 0.05 & 0.09 & 99 & 1.2 & 0.01 & 0.02 & 0.07 & 0.03 & 1.4 \\
\hline DSO_8 & & 0.02 & 0.05 & 0.08 & 99 & 1.3 & 0.01 & 0.03 & 0.04 & 0.02 & 1.5 \\
\hline Detection limit (ppm) & & 250 & 200 & 150 & 0.1 & 5 & 200 & 510 & 200 & 10 & $\ldots$ \\
\hline
\end{tabular}

instrumental settings, procedure described by Rademakers et al. (2018a, b)). To calculate the LI ratios, a blank correction was carried out and the measured intensities for ${ }^{202} \mathrm{Hg}^{+}$were used to correct for $\mathrm{Hg}$ contribution to the apparent intensity for the ${ }^{204} \mathrm{~Pb}^{+}$isotope. The raw sample ratios thus obtained were corrected for Tl-based mass discrimination following Russel's law, based on replicate measurements of the NIST SRM 981 common lead standard (commonly accepted ratio values from Galer and Abouchami (1998)); $2 \sigma$ uncertainties were better than ca. $0.01 \%$ for the corrected ratios to ${ }^{204} \mathrm{~Pb}$ and better than $0.005 \%$ for ratios to ${ }^{206} \mathrm{~Pb}$ (with the exception of sample SHM004, for which lead concentrations were very low: $2 \sigma$ uncertainties were still good at ca. $0.02 \%$ for the corrected ratios to ${ }^{204} \mathrm{~Pb}$ and $0.006 \%$ for ratios to ${ }^{206} \mathrm{~Pb}$ ). The LIA data are listed in Table 3 and plotted on Figs. 4, 5, 6 and 7.

\section{Macrostructure analysis}

The examinations of the macrostructure of the DSOs were carried out in the Laboratory of Historical Layers Research Centre at AGH University of Science and Technology (Poland) using the Nikon SMZ 745Z stereoscopic microscope (OM) equipped with the Nikon Digital Sight DsFil microscope camera. The aim of these examinations was to determine the manufacturing technology of the analysed artefacts.
The macrostructure analysis results are listed in Table 4 and plotted on Figs. 9 and 10.

\section{X-ray defectoscopy}

The X-ray defectoscopy was conducted in the Laboratory of Foundry Research Institute in Kraków (Poland) using an industrial X-ray radioscopy system, Y.MU2000-D (YXLON), comprising an X-ray tube $(160 \mathrm{kV})$ coupled with a digital panel detector with the active area of $200 \mathrm{~mm} \times 200 \mathrm{~mm}$ at the frame rate of $15 \mathrm{fps}$ and the pixel size of $200 \mu \mathrm{m}$. Data imaging was performed with the use of the YXLON Image 2500/3500 system. The X-ray defectoscopy results are plotted on Fig. 11.

\section{CT}

The computer tomography (CT) examination was employed to explore the manufacturing technology of the DSO 2 from Kałdus. The CT investigations were carried out in Nicolaus Copernicus Specialist City Hospital in Torun (Poland) using a clinical Philips Brilliance 16 Slice CT Scanner equipped with the Philips 8.0 MHU MRC X-ray tube. The artefact was positioned perpendicularly to the bore of the $\mathrm{CT}$ and imaged at the following parameters: $120 \mathrm{kV}, 50 \mathrm{~mA}, 3900 \mathrm{~ms}$ and $0.8 \mathrm{~mm}$ slice thickness. The CT scans were processed further

Table 3 Lead isotope data for the Rudki-type double spiral ornaments from Poland

\begin{tabular}{|c|c|c|c|c|c|}
\hline Signature & Site & $208 / 206$ & $207 / 206$ & $206 / 204$ & Consistent with the ores from: \\
\hline DSO_1 & Kałdus, Chełmno dist. & 2.07713 & 0.84194 & 18.59472 & Špania Dolina-Banská Bystrica-Kremnica, Slovakia \\
\hline DSO_2 & & 2.08440 & 0.84427 & 18.55239 & Špania Dolina-Banská Bystrica-Kremnica, Slovakia \\
\hline DSO_3 & Przeuszyn, Ostrowiec Świętokrzyski dist. & 2.08589 & 0.84752 & 18.43601 & Špania Dolina-Banská Bystrica-Kremnica, Slovakia \\
\hline DSO_4 & & 2.08789 & 0.84583 & 18.50796 & Špania Dolina-Banská Bystrica-Kremnica, Slovakia \\
\hline DSO_5 & & 2.09723 & 0.85396 & 18.26647 & Špania Dolina-Banská Bystrica-Kremnica, Slovakia \\
\hline
\end{tabular}


using the Philips DICOM Viewer R3.0-SP03 software. The CT results are plotted on Fig. 12.

\section{Microstructure analysis}

The microstructure analyses were performed in the Laboratory of Historical Layers Research Centre at AGH University of Science and Technology (Poland) using the Nikon Eclipse LV150 metallographic microscope (OM) equipped with a Nikon Digital Sight DsFil microscopic camera and the NisElements system for a picture analysis. The OM observations were conducted in the cylindrical links exposed on the DSO_2 (Kałdus) and DSO_6 (Rudki). The microareas were polished with diamond paste $(1 \mu \mathrm{m})$ and etched in $\mathrm{HCl}(30 \mathrm{ml})+\mathrm{FeCl}_{3}$
$(30 \mathrm{~g})$ in $\mathrm{C}_{2} \mathrm{H}_{5} \mathrm{OH}(120 \mathrm{ml})$ solution. The microstructure analyses results are plotted on Fig. 13.

\section{${ }^{14} \mathrm{C}$ dating}

In order to narrow the probability ranges of the chronological placement of the Rudki-type DSO, radiocarbon dates were obtained for three individual bone samples collected from two features recovered from the TRB settlement in Kałdus (see Table 1). The samples were ${ }^{14} \mathrm{C}$-dated in the AMS ${ }^{14} \mathrm{C}$ Laboratory of the Adam Mickiewicz University in Poznań by routine laboratory procedures for bone samples described by Goslar (2018). Calibration of ${ }^{14} \mathrm{C}$ age was modelled in $\mathrm{OxCal}$ v. 4.2.3 (Bronk Ramsey and Lee 2013) using IntCal13 calibration curve (Reimer et al. 2013).
Fig. 4 Comparisons of lead isotope ratios to the nonradiogenic ${ }^{204} \mathrm{~Pb}$ of the DSOs found in Poland with the data for ores that contain minerals marginally isotopically consistent with their lead isotope ratios. Lead isotope database for Spanish ores includes about 1000 datasets, here only the copper ores that are known to be exploited in the Chalcolithic period are plotted. The lead isotope ratios for the DSOs plot between the groups of these deposits
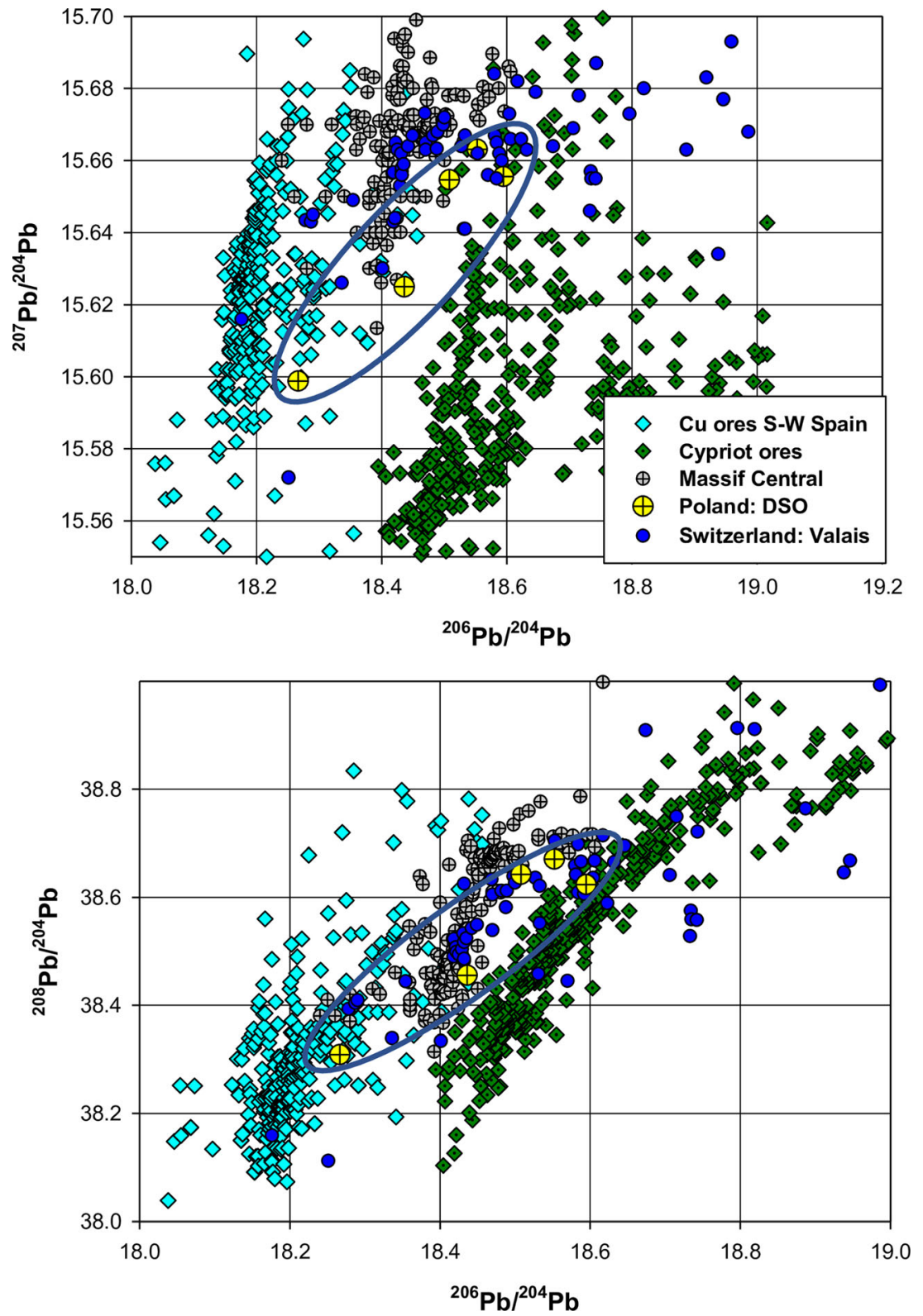
Fig. 5 Comparisons of lead isotope ratios to the radiogenic ${ }^{206} \mathrm{~Pb}$ of the analysed DSOs with the ores from the Slovak

Carpathians and the Harz

Mountains indicate that these ornaments have compositions consistent with the Slovak ore deposits in Špania Dolina and Banská Štiavnica. The upper plot clearly shows that the ores from Harz plot below the ores from Slovakia and the analysed DSOs
니 1
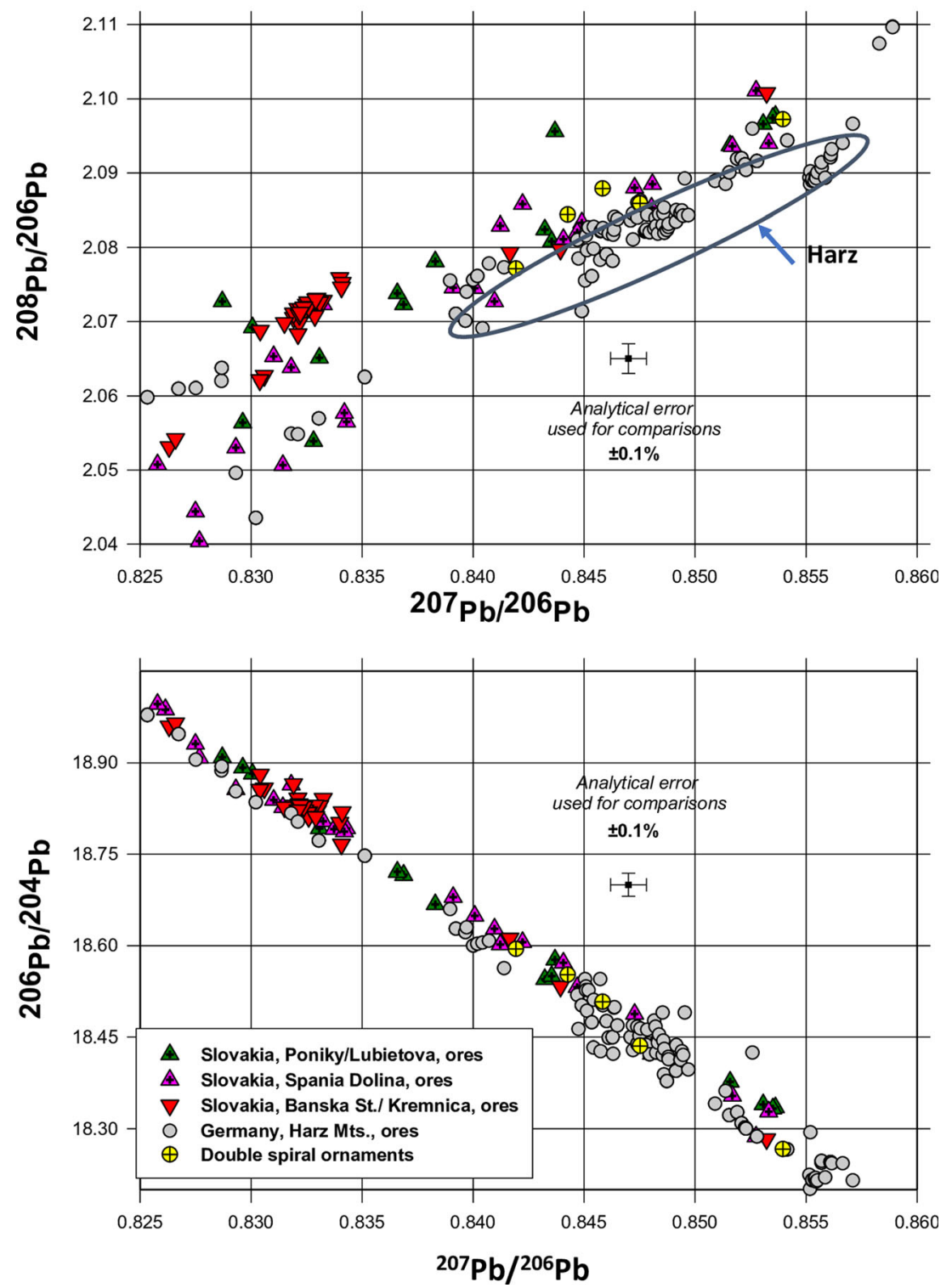

The ${ }^{14} \mathrm{C}$ dates processing was performed with the use of the Sum and $R$ _Combine commands, proposed by Bronk Ramsey (2009, 2017), and completed by testing in the environment of the OxCal v. 4.3 software with IntCal13 (Reimer et al. 2013). The resulting outcome was rounded to 10 years and presented with 68.2 and $95.4 \%$ confidence intervals. The ${ }^{14} \mathrm{C}$ data are listed in Tables 1 and 5 and plotted on Figs. 15, 16 and 17.

\section{Results and discussion}

The results of the examinations of the Rudki-type DSOs were divided into two main parts. In the first part, there is a discussion of the trace elemental compositions of the ornaments analysed using ED XRF (and comparisons with other artefacts of similar chronology) and the results of lead isotope analyses of five of double spiral ornaments. The second part is devoted to the study of the manufacturing technology (OM, X-ray, CT) of these ornaments.

\section{Trace elemental characterisation}

The ED XRF analyses show that Rudki-type DSOs are made of unrefined copper (98-99 wt\% in all cases; Table 2). The iron contents measured in the ornaments are in all cases less than $0.1 \mathrm{wt} \%$, which is in line with the chemical compositions reported by Junghans et al. (1974) for the Eneolithic metalwork, where the iron content is expected to remain below the 
Fig. 6 Comparisons of lead isotope ratios of Neolithic/ Eneolithic copper artefacts from Slovakia (Schreiner 2007) and double spiral ornaments from Polish sites show clearly that majority of artefacts in both groups are consistent with the lead isotope characteristics of ores from the Slovak Ore Mountains. In this plot, there are also included data for various ore samples from the region of Salzburg which have lead isotope ratios similar to some of the ornaments. However, these ores have to be rejected as source of copper for these artefacts, because there are lead ores and Fahlores, therefore chemically not consistent with the DSOs
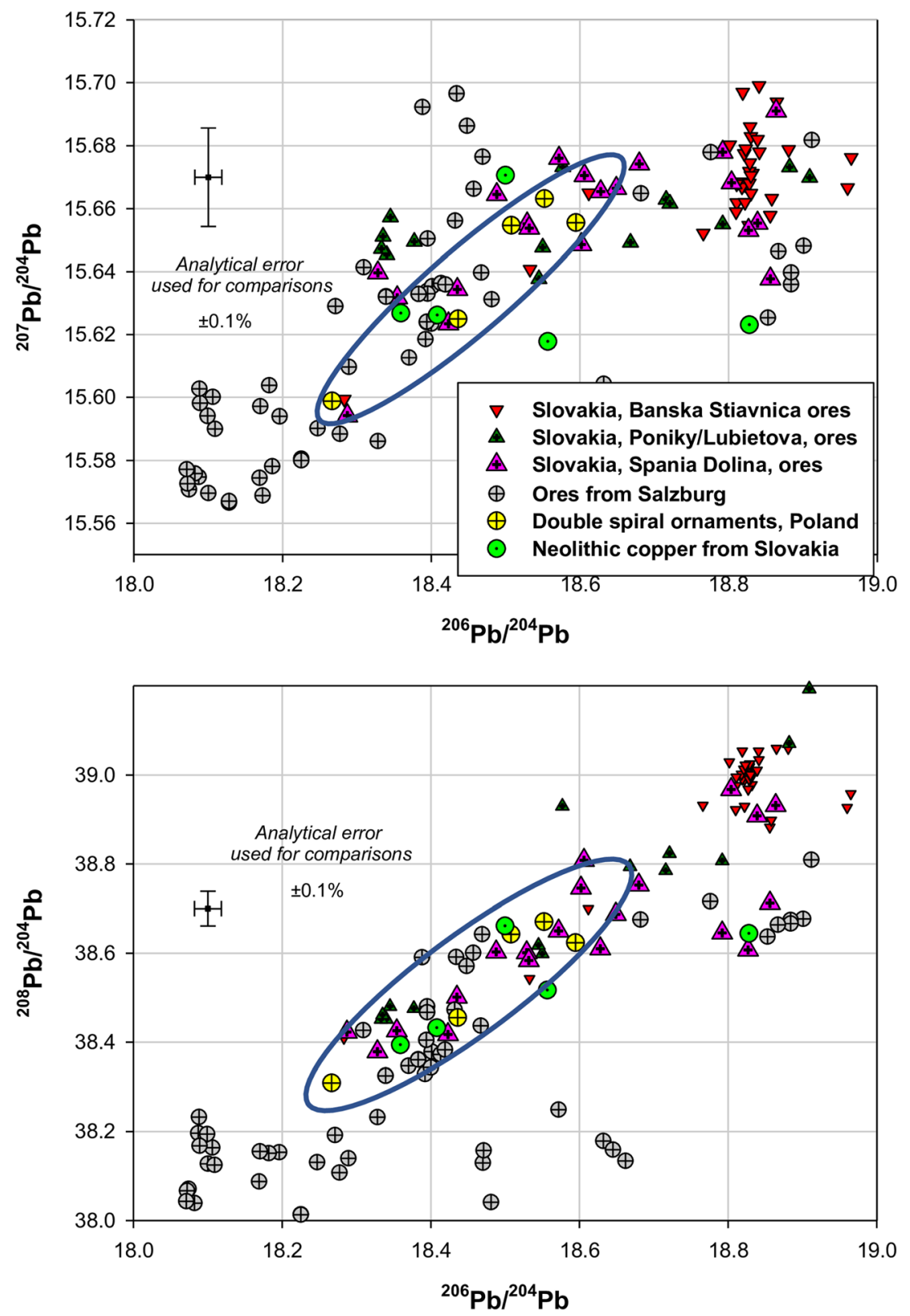

value of $1 \mathrm{wt} \%$ (Cook and Aschenbrenner 1975, p. 253; Kadar 2002, p. 13). Cobalt, nickel, silver, antimony and bismuth are all below $0.1 \mathrm{wt} \%$, while the arsenic content varies between 0.2 and $1.3 \mathrm{wt} \%$.

Lead content is in all case below $0.25 \mathrm{wt} \%$, which is quite typical for the earliest copper artefacts found in Europe. In the double spiral ornaments from the Kałdus hoard, the lead content is higher than in the other artefacts analysed for this project, but not unusual as a natural impurity of copper ores used in the Prehistoric times. On the whole, the level of impurities in the analysed DSOs is very low, indicating copper smelted from oxidised or sulphidic ores (not from Fahlerz). With a major contribution made by arsenic, the total content of impurities averages from 0.5 to $1.7 \mathrm{wt} \%$ (see Table 2).
The chemical compositions of the double spiral ornaments from Poland represent pure copper and correlate chemically well with clusters 1 and 2 defined by Krause (2003, pp. 90-1 and 322, Abb. 40 and 41) as 'pure copper' (= A:1) and 'copper with low amounts of arsenic and nickel' (= A:2). It can also be noted that a metal type that is characteristic of the Rudki-type DSOs closely resembles the so-called Mondsee copper (Frank and Pernicka 2012, pp. 120-4, Table 1, Figs. 5.4 and .5).

\section{Interpretation of the lead isotope analyses}

The lead isotope data obtained for the five double spiral ornaments from Poland is listed in Table 3. 
니 3
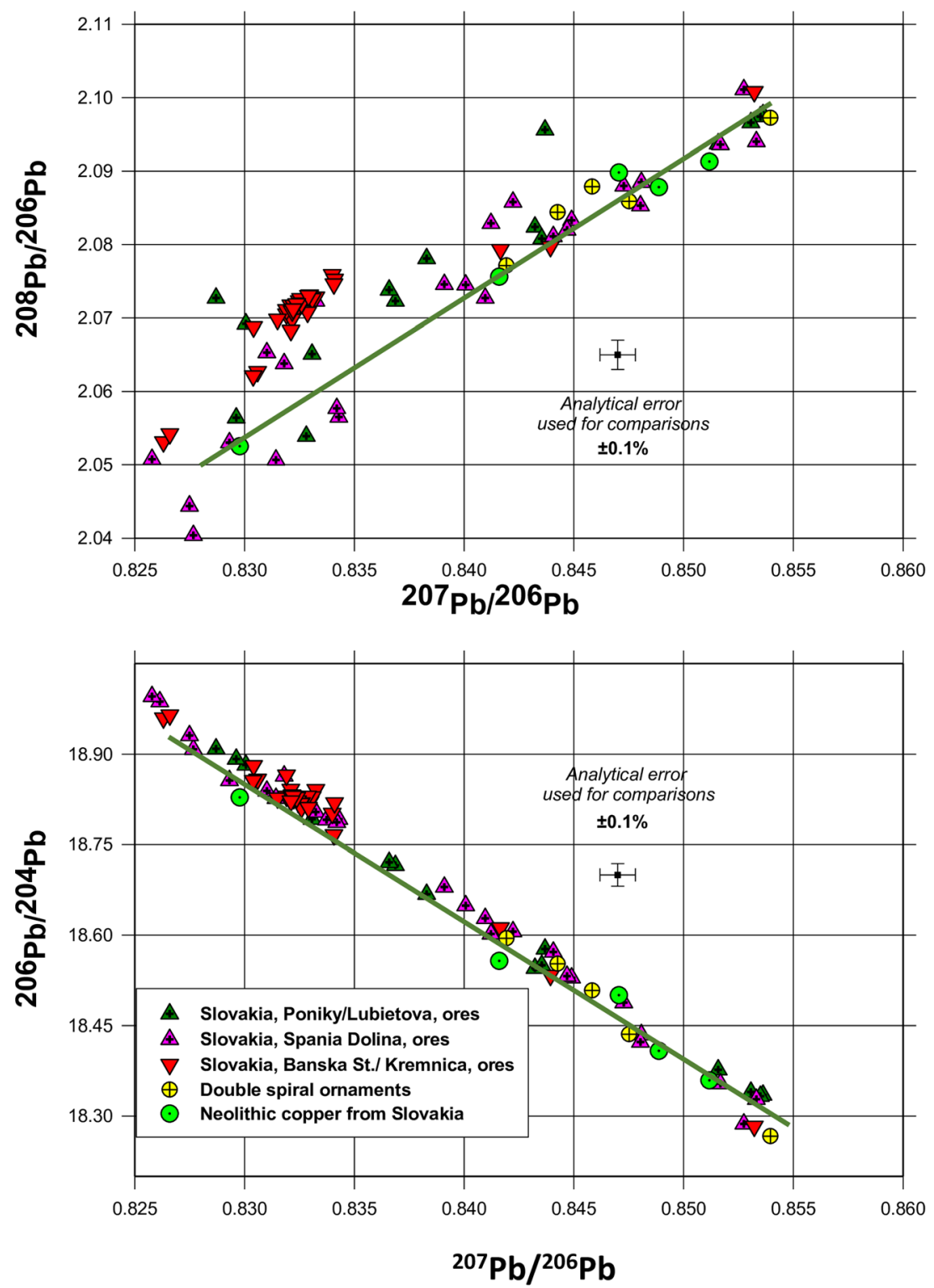

Fig. 7 Comparisons of lead isotope ratios to the radiogenic ${ }^{206} \mathrm{~Pb}$ of the analysed DSOs, the Neolithic/Eneolithic copper artefacts from Slovakia and ores from the Slovak Ore Mountains show that all their lead isotope ratios lie on a straight line within the analytical error, providing further evidence of their origin from the same ore deposit
The lead isotope research into provenance of ancient metals relies on the identification of ore deposits that were used for production of metals in antiquity via direct comparisons of available lead isotope data for minerals from different mines and the data obtained from samples of ancient artefacts. The interpretation of the data is based on several steps (Stos-Gale and Gale 2009; Ling et al. 2014):

The initial stage of identifying the possible sources of archaeological artefacts includes: i. Finding for each artefact the ore samples that have identical (within $\pm 0.1 \%$ of the error) all three lead isotope ratios. This is done using the TestEuclid procedure (Stos 2009, p. 168) searching through the database covering all ore data.

ii. Plotting the lead isotope ratios of the artefacts on 2-D lead isotope diagrams for at least three independent lead isotope ratios (most often they are three ratios to ${ }^{204} \mathrm{~Pb}$, or two to ${ }^{206} \mathrm{~Pb}$ and one to ${ }^{204} \mathrm{~Pb}$ ) together with the data for all ore deposits that appeared to show matching lead isotope 
Table 4 The dimensions of the Rudki-type double spiral ornaments from Poland. The length is expressed as a value calculated after hypothetical stretching the ornament. The units of length and weight are centimetres and grams, respectively

\begin{tabular}{|c|c|c|c|c|c|c|c|c|c|}
\hline \multirow[t]{2}{*}{ Signature } & \multirow[t]{2}{*}{ Site } & \multicolumn{3}{|c|}{ Number of turns } & \multicolumn{4}{|l|}{ Length } & \multirow[t]{2}{*}{ Weight } \\
\hline & & Coil 1 & Coil 2 & Linkage & Coil 1 & Coil 2 & Linkage & Total & \\
\hline DSO_1 & \multirow[t]{2}{*}{ Kałdus, Chełmno dist. } & 7 & 7 & 4 & 51 & 50 & 17 & 118 & 53 \\
\hline DSO_2 & & 9 & 9 & 6 & 136 & 127 & 31 & 293 & 352 \\
\hline DSO_3 & \multirow[t]{3}{*}{ Przeuszyn, Ostrowiec Świętokrzyski dist. } & 8 & 8 & 5 & 67 & 65 & 18 & 150 & 133 \\
\hline DSO_4 & & 9 & 9 & 4 & 80 & 78 & 16 & 174 & 162 \\
\hline DSO_5 & & 7 & 7 & 4 & 52 & 49 & 16 & 117 & 124 \\
\hline DSO_6 & \multirow[t]{3}{*}{ Rudki, Szamotuły dist. } & 9 & 9 & 5 & 114 & 116 & 16 & 246 & 172 \\
\hline DSO_7 & & 9 & 9 & $>3$ & $>97$ & $>108$ & $>12$ & $>217$ & $>132$ \\
\hline DSO_8 & & 7 & $>5$ & $>3$ & 79 & $>46$ & $>12$ & $>137$ & $>55$ \\
\hline
\end{tabular}

ratios in the TestEuclid procedure. The plots allow consideration of the mutual position of groups of analysed ores from various ore deposits relative to the groups formed by LI ratios representing the archaeological artefacts.

The second stage of the process of interpretation of the analytical data considers a broader picture of the possible origin of metals including:

i. Rejection of the ore deposits that on geochemical or chronological ground could not have supplied copper for these artefacts.

ii. Comparisons with the lead isotope and elemental data for contemporary artefacts from the same region.

In this case, the TestEuclid comparisons were made with the database of about 8000 sets of lead isotope data from the deposits of copper and lead/silver ores in Europe and the Near/ Middle East. This test indicated that for each of the spiral ornaments analysed there are many single ore samples from various localities, for example Cyprus, Southern Spain, Massif Central in southern France, the Austrian Alps or Valais in Switzerland, that have very similar lead isotope compositions. However, the ores from these locations either do not have chemistry matching the DSOs or are from localities that are not likely to have been exploited in the 4th millennium BC. ${ }^{1}$ Further, the lead isotope plots show that the lead isotope data obtained for the DSOs from Poland plot between and on the edges of the groups of data for these ores as shown on Fig. 4. Also, the group of copper ores from the Harz Mountains in SE Germany has lead isotope ratios

\footnotetext{
${ }^{1}$ Further proof for rejecting the copper ore deposits in Cyprus, Southern Spain and Massif Central in southern France as a possible origin for copper metal used for making the DSO from Poland comes from a general archaeological overview of the exchange network in the Eneolithic Europe. There is currently no conclusive archaeological evidence supporting any forms of cultural contact between the Eneolithic communities from Cyprus and Southern Spain with the dominium of the Baden culture complex (see, e.g. Furholt 2009; Sochacki 1981).
}

that are very close to the whole group of these ornaments. However, the only group of copper ores chemically and isotopically fully consistent with the analysed DSOs is found in the Slovak Ore Mountains (Fig. 5). All five analysed DSOs have lead isotope ratios fully consistent with the ores from the Hron Valley mining region (= Hrontal), including Špania Dolina, Banská Štiavnica and Kremnica published by Schreiner (2007, pp. 245-51). It needs to be emphasised that these published data are obtained by two different methods of isotope analyses: data marked 'Bri' were taken in Bristol University using a quadrupole ICP-MS, this instrument does not allow for measurements of lead isotope ratios with overall better accuracy than $1 \%$ and the ion beams of the isotope ${ }^{204} \mathrm{~Pb}$ are too weak to be measured (The University of Texas in Austin 2017). Therefore, from the tables of data included in the Schreiner's publication, only the MC-ICP-MS data from Mannheim marked (MA) can be used for comparisons.

The comparative plots of the ores from the Slovak Ore Mountains and the Harz demonstrate clearly that lead isotope ratios to ${ }^{206} \mathrm{~Pb}$ for the samples of ores from the Harz Mountains plot in line below the ores from the Slovak deposits (Fig. 5). This is not surprising, because the chronology of exploitation of the copper ores in the Harz Mountains does not include the Eneolithic mining, but Schreiner (2007) indicates very early copper mining in the Slovak Hrontal mines. This statement is reasserted by O'Brien (2015, pp. 186-7).

Schreiner analysed for their lead isotope compositions six copper-based artefacts from Slovakia dated to the Neolithic period (= Ludanice horizon $\left.{ }^{2}\right)$. They include two spirals and a

\footnotetext{
${ }^{2}$ The beginnings of copper mining in Central Slovakia are placed in the Ludanice group (= TRB-MES I; 4100-3800 cal BC) in Slovenskè Pravno and the Špania Dolina mine located $35 \mathrm{~km}$ east of this site and several late Eneolithic settlements from the Zvolen basin (Modarressi-Tehrani and Garner 2015, p. 46; Müller 2012, p. 54, Abb. 8; Müller et al. 2012; O’Brien 2015, pp. 186-7; Schreiner et al. 2012, p. 357; Točik and Žebrak 1989; p. 72; Žebrák 1995, pp. 14-5). The results of our study provide another indirect proof for the copper mining at the Slovak Ore Mountains (Špania Dolina-Banská BystricaKremnica mine complex) during the Boleráz period (= TRB-MES III; 35003350 cal BC).
} 
Table 5 The modelling procedure of the ${ }^{14} \mathrm{C}$ dates obtained for the Rudki-type double spiral ornaments from Kałdus (Poland). The resulting model indicates a $3510-3350 \mathrm{cal} \mathrm{BC}$ date range (with a $95.4 \%$ probability)

\begin{tabular}{|c|c|c|c|c|c|c|c|}
\hline \multirow[t]{2}{*}{ Signature } & \multirow[t]{2}{*}{ Lab. no. } & \multirow[t]{2}{*}{ Procedure } & \multirow[t]{2}{*}{ Age BP } & \multicolumn{2}{|c|}{ Calibrated age } & \multicolumn{2}{|c|}{ Modelled age cal BC } \\
\hline & & & & $68.2 \%$ & $95.4 \%$ & $68.2 \%$ & $95.4 \%$ \\
\hline DSO_1 & Poz-97720 & \multirow[t]{2}{*}{ R_Combine } & 4620,40 & $3510-3360$ & $3620-3350$ & \multirow[t]{2}{*}{$3500-3360$} & \multirow[t]{4}{*}{$3520-3350$} \\
\hline DSO_1 & Poz-97721 & & 4640,40 & $3500-3350$ & $3520-3130$ & & \\
\hline DSO_2 & Poz-95657 & \multirow[t]{2}{*}{ Sum } & 4640,40 & $3510-3360$ & $3620-3350$ & \multirow[t]{2}{*}{$3660-3000$} & \\
\hline DSO_-1 & (Combined) & & $\ldots$ & $3500-3360$ & $3520-3350$ & & \\
\hline DSO_1 & Poz-97720 & \multirow[t]{3}{*}{ R_Combine } & $\ldots$ & $3510-3360$ & $3620-3350$ & \multirow[t]{3}{*}{$3500-3360$} & \multirow[t]{3}{*}{$3510-3350$} \\
\hline DSO_1 & Poz-97721 & & $\ldots$ & $3500-3350$ & $3520-3130$ & & \\
\hline DSO_2 & Poz-95657 & & $\ldots$ & $3510-3360$ & $3620-3350$ & & \\
\hline
\end{tabular}

four-sided awl from Čertova cave near Radošina (SAM 17677, 78 and 9), an armband from Komjatice (SAM 22326) and a casting piece from Nitriansky Hrádok (SAM 10980) (Schreiner 2007, pp. 221 and 251). The lead isotope ratios to ${ }^{204} \mathrm{~Pb}$ published for these artefacts are compared on Fig. 6 (presenting sets of lead isotope ratios to non-radiogenic ${ }^{204} \mathrm{~Pb}$ ), together with the data for the ores from the Slovak Ore Mountains in Hron Valley and the double spiral ornaments from Poland. This plot demonstrates total consistency of all these Neolithic/Eneolithic artefacts with the ores from Špania Dolina and Poniky/L'ubietová. On the same plot, included are some ores from the Austrian Alps in the region of Salzburg, that also have similar lead isotope ratios. However, these ores are either lead ores (galenas) or Fahlores with high concentrations of silver and antimony. Neither of these minerals could have provided raw material for smelting copper ores of high purity as found in the analysed DSOs, or the copper artefacts from Slovakia. Further comparisons of the lead isotope ratios for these copper artefacts and the ores from Slovakia using the ratios to the radiogenic isotope ${ }^{206} \mathrm{~Pb}$ (Fig. 7) show very good linearity (within the analytical error) of all these data which is a further argument towards the conclusion that copper used for these early ornaments originated in the Slovak Ore Mountains.

The chemistry of the analysed double spiral ornaments is broadly similar to the Slovak copper spirals. Their analyses indicate that they were made from very pure copper (Schreiner 2007, p. 232). The double spiral ornaments found in Poland have higher contents of arsenic, which means that the Slovak and Polish artefacts were not made from the same batch of minerals. Schreiner (2007, p. 40) describes the mineralogy of the ores in Hron Valley as a mixture of sulphides and oxidised ores. It is possible that the earliest copper metallurgy in this region was utilising the rich oxidised ores with varied contents of arsenic. Smelting of such ores does not require roasting; therefore, the amount of arsenic in the smelted metal can vary depending on its content in the ore, as explained by Frank and Pernicka (2012, pp. 122-4). In his publication, Schreiner (2007, pp. 230-1) divided the ores into eight clusters according to their chemistry. The Neolithic/Eneolithic copper artefacts from Slovakia in his study correlate chemically very well with cluster 5 (Fig. 8), which represents very pure copper ores from Kremnica, L'ubietová, Špania Dolina and others. Clusters 2 and 7, which include ores higher in arsenic, but comparatively low in other elements, also consist of ore samples from Špania Dolina, L'ubietová and Poniky (amongst others). It is clear from this clustering, that in each of the sites in Hron Valley, there are ores of different chemistry. Consequently, depending on the batch of ores collected for smelting, the chemical compositions of the smelted ores can vary. The lead isotope ratios of the Polish and Slovak copper artefacts indicate that both sets are consistent with copper ores from Hron Valley but their chemistry indicates that the copper for each of these two groups was obtained from different batches of oxides, not tetrahedrites (non-Fahlerz), possibly originating not from one mine, but collected widely from the region. On the lead isotope plot of the ores from Hron Valley and the Neolithic/Eneolithic artefacts from Poland and Slovakia, the green line indicates such mixing between the ores from Špania Dolina and Poniky/L'ubietová.

\section{Manufacturing technology}

The analysed artefacts were designed to have very similar shape and dimensions which is clearly visible in the number of turns forming the flat spirals and a type of cylindrical linkage (Table 4). The number of turnings ranges from 7 to 9 and from 4 to 6 , and it seems that this is a standard for the analysed artefacts. It is important to mention that neither a pin, nor any remains of a spring, or a catch plate was found on the surfaces of these ornaments.

The macroscopic observations (OM) showed that joint areas are present on the turns forming the flat spirals. The joints are in the form of thin-shaped edges overlapping the central part of the rod (see, e.g. Figs. 9a, 1 and 10a, k, 1), indicating that the Eneolithic metalworker could have employed the cramped joint for combining the individual copper rods into one part, before he or she proceeded to coil the resulting rod. The results provided by the X-ray defectoscopy 

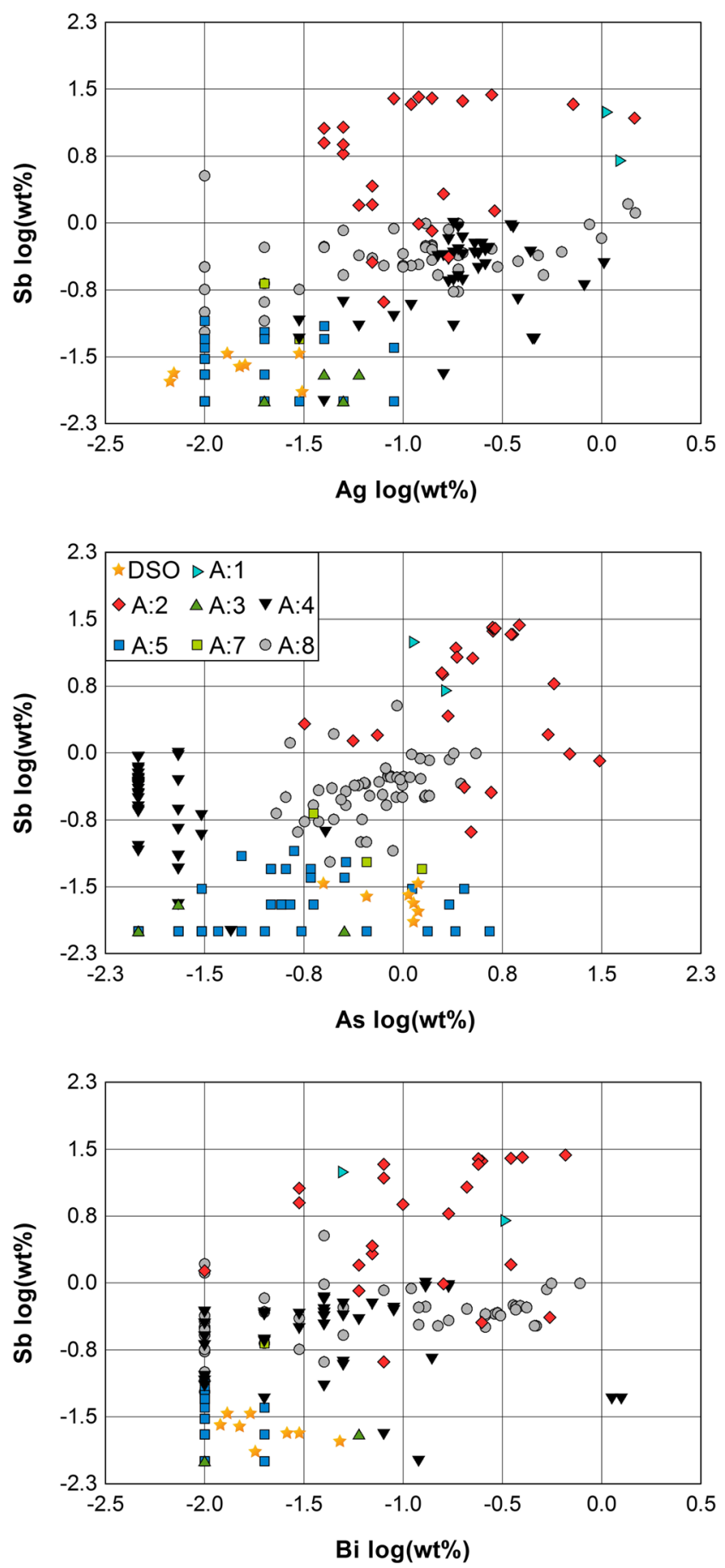

Fig. 8 Chemical characteristics of the copper used in Neolithic/Eneolithic copper artefacts from Slovakia and the Rudki-type double spiral ornaments from Poland. The two-element diagrams Ag vs. Sb, As vs. Sb and $\mathrm{Bi}$ vs. Sb each show chemical correlation between the double spiral ornaments and cluster 5 (Schreiner 2007, adapted)

(Fig. 11) and CT imaging (Fig. 12) lend unequivocal support to this conclusion.

The Rudki-type DSOs are technologically coherent, and indicative of a five-step chaîne opératoire implementation, which involved: i. Plastic working of the starting material, i.e. shaping and elongating the individual copper rods (possibly rodshaped copper ingots).

ii. Mechanical combining of the individual rods into a long rod with the use of a cramped joint.

iii. Forming the cylindrical linkage and the flat spirals respectively by coiling the long rod.

iv. Hammering the spirals into place to tighten the coils. This procedure affected also the shape of the rod making its cross-section nearly hexagonal (see, e.g. Figs. 9c, g and $10 \mathrm{j}$ ). It is likely that stabilising (wooden?) blocks needed to be employed during this stage to keep the spirals in place.

v. Rubbing with a polishing stone, to obtain a smooth and shiny surface of the final product (see, e.g. Figs. 9c, d and $10 \mathrm{i}, \mathrm{k})$.

The results of the microstructure analysis $(\mathrm{OM})$ made a significant contribution to the above conclusions. In the microstructure of the DSO_2 and DSO_6, recrystallised and twinned grains with strain lines are absent and straight twin lines locked in the grains are noticeable (Fig. 13). The presence of the twinned grains (Fig. 13c) suggests that the copper rod might have been re-forged hot, or, which is more probable, was cold-worked and annealed (Kienlin 2011, p. 134; Scott 1991, pp. 7-8). Further proof of this process comes from the step-like microstructures which are evident in the microarea of the DSO_6 (Fig. 13f). Particularly, this technological scenario is relevant to the stage of forming a cramped joint because the metalworker had to find a way of mechanical combining individual copper ingots into one part and to ensure durability and strength of such connection.

The general morphological characteristics do not allow a clear technological distinction between the Eneolithic and the LBA/EIA double spiral ornaments (see, e.g. the Lusatian ornaments from Karmin and Lubiąż (Gedl 2004, pp. 159-61, Taf. 69; Suchy et al. 2016, p. 158, Fig. 13)). It is clear from this study that a technique of preparing the starting material (i.e. rod) for production of a double spiral ornament is a decisive factor in defining technological differences between the Rudki-type and the later spiral metalwork. While the metalworkers practicing during the LBA and EIA applied a long hammered (round) rod for coiling a double spiral ornament (see, e.g. Gedl 2004), the Eneolithic specimens were made of mechanically combined short rods. ${ }^{3}$

It is not certain whether a cramped joint is the hallmark of the Eneolithic spiral metalwork, though there are many copper findings that provide such justification: for example, the spiral armbands deposited in the Rudki hoard also show the cramped joints (Fig. 14).

\footnotetext{
${ }^{3}$ So far, there is no conclusive evidence that could support mastering the soldering technique (e.g. brazing alloy) by the Eneolithic metalworkers from Central Europe.
} 
Fig. 9 The macrostructures of the Rudki-type double spiral ornaments from Poland: DSO_1 (a-c; Kałdus), DSO_2 (d-f; Kałdus), DSO 3 (g-i $\mathbf{i}$; Przeuszyn) and DSO_4 (j-l; Przeuszyn). The cramped joints (indicated by red arrows) preserved in the form of thin-shaped edges overlapping the central part of the rod
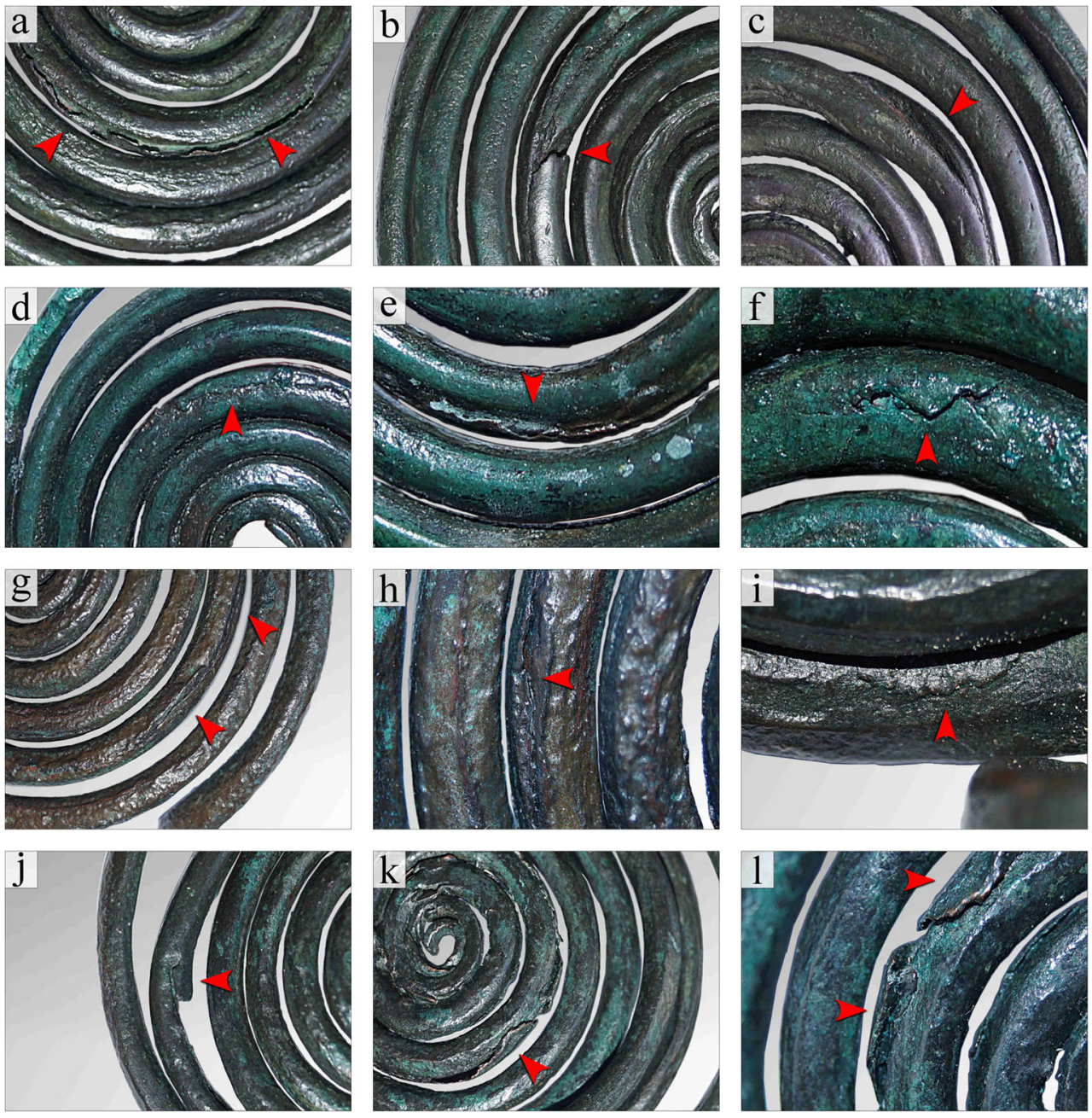

\section{Chronological placement}

Three radiocarbon dates collected from Kałdus are quite consistent (see Table 1). A time-frame for the DSO_1 deposition was established by narrowing the probability ranges of two bone samples with the use of the $R$ Combine procedure (Fig. 15 and Table 5). Due to a significant consistency between the dates and a slight plateau on the calibration curve, this procedure has not made a significant contribution (and the same applies to the sum of probability density model (Fig. 16 and Table 5)). However, because the results of the metallographic and archaeological investigations suggest that the DSOs could have been hoarded in Kałdus at or about the same time (see Table 1), the $R \_$Combine procedure was re-applied for all three available radiocarbon dates (see, e.g. Bronk Ramsey et al. (2010) for opinion about an archaeological approach). ${ }^{4}$

A $74.9 \%$ likelihood scenario provided by the results of the 95.4\% probability distributions shows two possible dates for

\footnotetext{
${ }^{4}$ The $R$ Combine procedure is routinely applied for the radiocarbon dates collected from the same material or stratigraphic context (see, e.g. Bronk Ramsey 2009, 2017).
}

the depositions of the DSOs in Kałdus: one that the DSOs have been deposited in Kałdus between 3510 and 3420 cal BC (Fig. 17); the other also possible is $3390-3350$ cal BC date range (see Fig. 17). Nonetheless, a radiocarbon result of 3510-3350 cal BC from Kałdus is still a very precise result for the chronological placement of the Rudki-type DSO (see Scott et al. (2007) for 'accurate' vs. 'precise'). However, a different model, involving a long-term metal(work) circulation, and thus extending social life of a metal(work) is also possible (see, e.g. Kowalski et al. 2016, 2017), but rather not applicable to the analysed ornaments, because in the pre-Baden there was no double spiral ornament tradition and no double spiral ornament images incised on the ceramic vessel. Also, the Rudkitype DSOs are technologically coherent and it is likely that a cramped joint is the hallmark of the Baden spiral metalwork. Why, then, a cramped joint has not been recognised in the earlier (pre-Baden) metalwork?

The results of metallographic investigations (see "Trace elemental characterisation", "Interpretation of the lead isotope analyses" and "Manufacturing technology" sections) may be used to indicate that the inflow of the 
Fig. 10 The macrostructures of the Rudki-type double spiral ornaments from Poland: DSO_5 (a-c; Przeuszyn), DSO_6 (d-f; Rudki), DSO 7 (g-i; Rudki) and DSO_8 (j-l; Rudki). The cramped joints (indicated by red arrows) preserved in the form of thin-shaped edges overlapping the central part of the rod
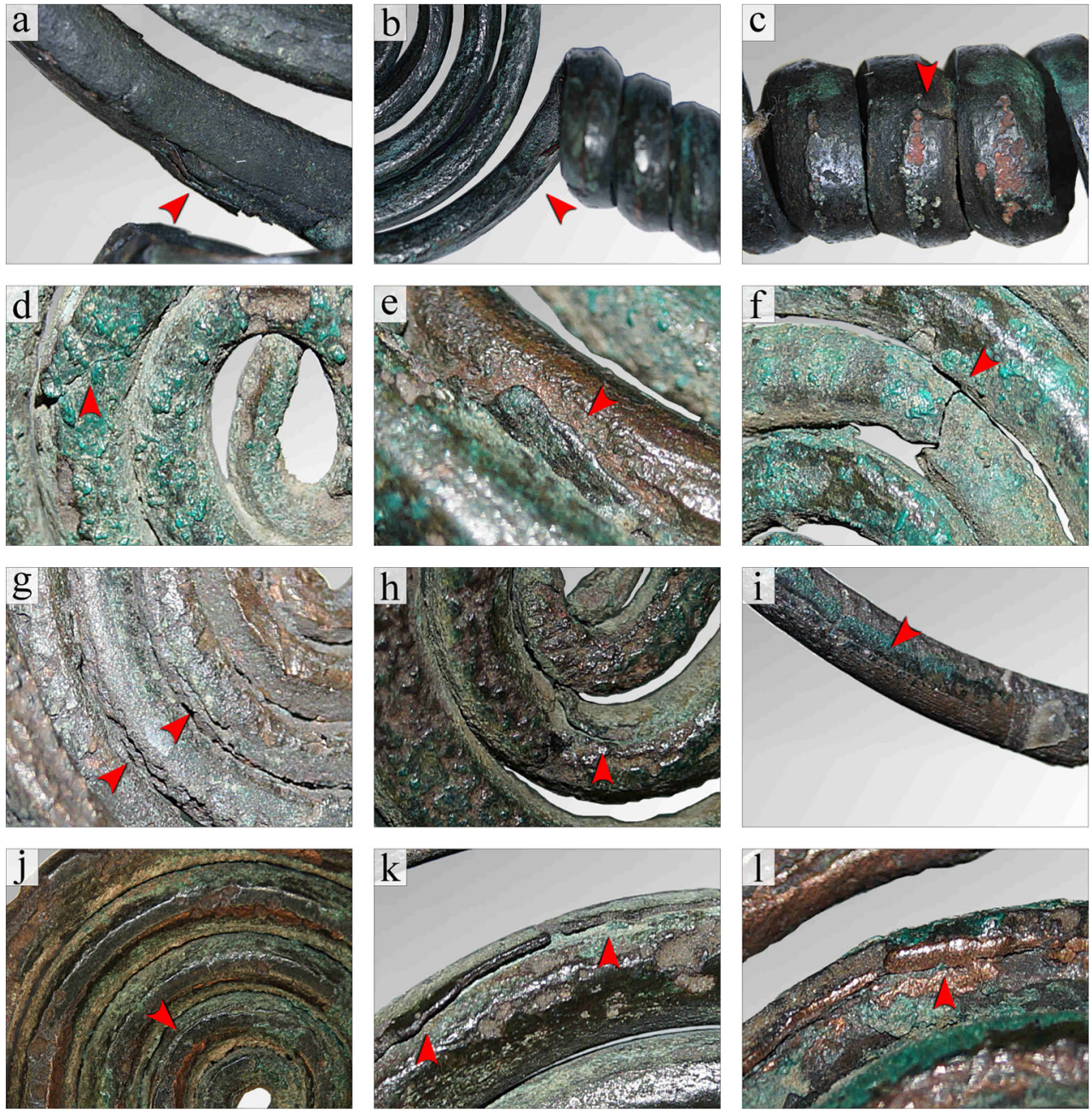

double spiral ornaments into the TRB milieu in the region of modern Poland bears the hallmark of a metallurgical horizon, and this conclusion is also supported by the settlement pattern and style of pottery. A wide range of $3650-3100 \mathrm{BC}$ is commonly used by an archaeologist in Poland to date the Baden copper metalwork (linked to the TRB) which cannot be ${ }^{14} \mathrm{C}$ dated (see, e.g. Adamczak et al. 2015a; see "Archaeological background" section), but in the case of DSOs from Przeuszyn and Rudki hoards, it seems now justified to change their chronological placement to $3510-3350 \mathrm{cal} \mathrm{BC}$, as defined by the metal finds from Kałdus.

\section{Back to the Eneolithic}

\section{Provenance and possible (re-)distribution channels}

The spatial distribution of the double spiral ornaments discussed in this paper can support the hypothesis that perhaps they could have been made in a workshop(s) inside the Vistula and Oder basins. However, this stands in sharp contrast with the fact that there is little, if any, archaeological evidence proving that copper working was indeed introduced by the local TRB communities in this region in the 4th millennium BC (see, e.g. Kowalski et al. 2016). Also, the apparent contradiction between the distribution pattern and the absence of the Rudki-type DSOs in the Carpathian Basin should not be used here as an argumentum ex silentio providing direct evidence supporting their local TRB origin. From these assumptions emerges a most convincing scenario that the analysed ornaments were made in the Baden culture workshop(s) somewhere in the Carpathian Basin, from which they were later redistributed towards the northern peripheries of the Baden complex (Fig. 18).

It seems plausible that circulation of the Eneolithic metalwork which overlapped the TRB ecumenes in the region of modern Poland was strongly allied with exchange routes established already during the TRB-MES I $(=4100$ 3800 cal BC; Adamczak et al. 2015b; Kowalski et al. 2016). Most likely, this was done via the routes maintained during the Hunyadihalom-Lažňany horizon (Wilk 2016, p. 20, Fig. 10). This trading route linking the areas of eastern Slovakia with 

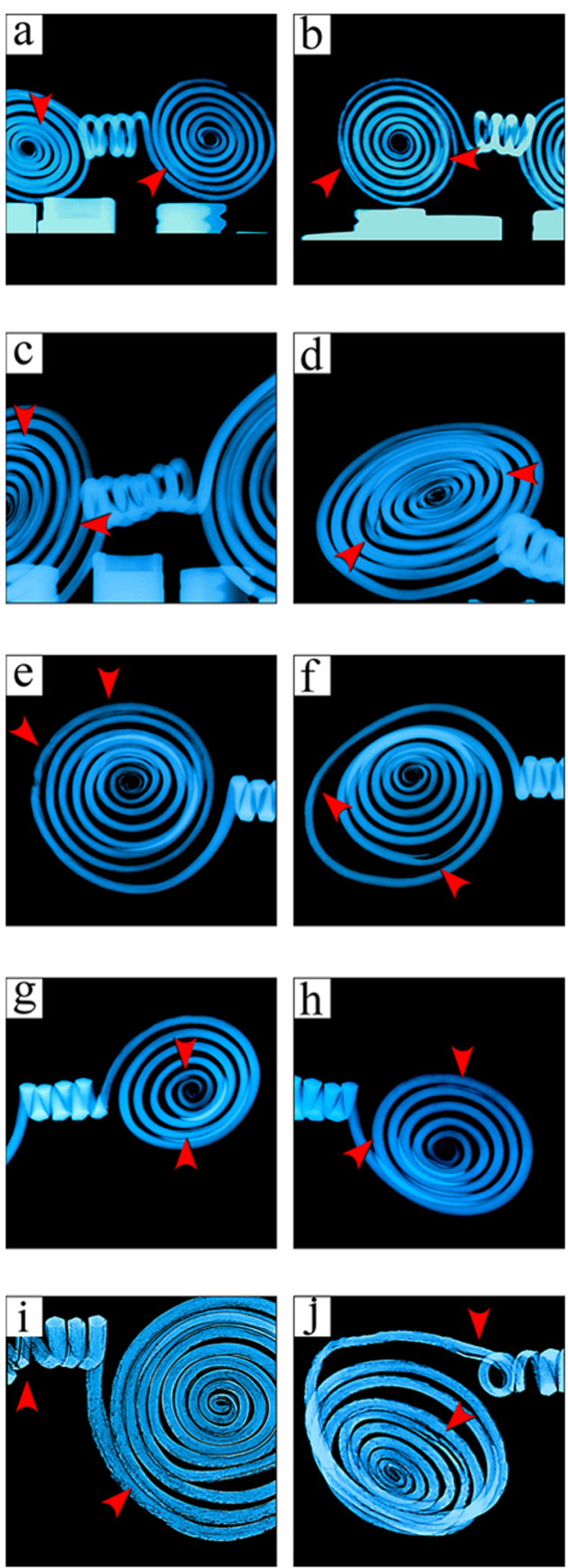

Fig. 11 The X-ray images of the Rudki-type double spiral ornaments from Poland: DSO_1 (a, b; Kałdus), DSO_2 (c, d; Kałdus), DSO_4 (e, f; Przeuszyn), DSO_5 (g, h; Przeuszyn) and DSO_6 (i, j; Rudki). The cramped joints are indicated by red arrows

western parts of Lesser Poland along the Hornád-PopradDunajec-Vistula axis ${ }^{5}$ (Zastawny and Horváthová 2017, p. 251), and running through Vistula Basin towards the northern

\footnotetext{
${ }^{5}$ The recent studies in both Northern and Central Slovakia (Horváthová and Zastawny 2016, Obr. 2; Struhár et al. 2015, p. 294, Fig. 7, Table 1; Zastawny and Horváthová 2017, p. 250, Ryc. 1) have confirmed the settlement activity of the communities sharing the Proto- and Boleráz tradition $(=3650$ $3350 \mathrm{cal} \mathrm{BC})$.
}
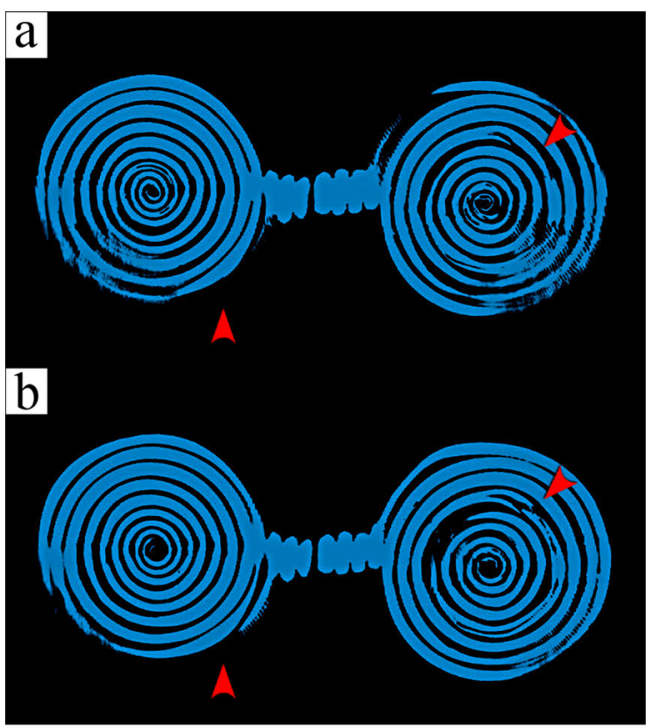

CRAMPED JOINT

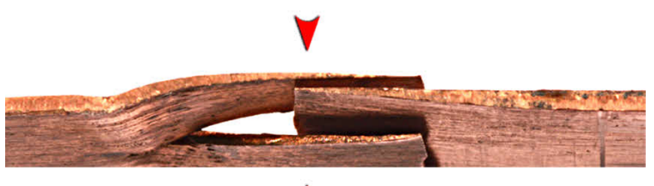

$A$
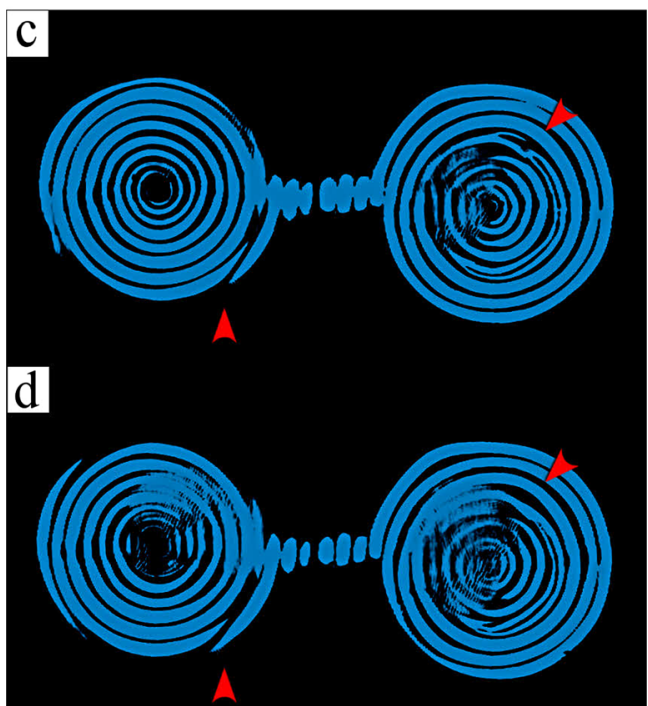

Fig. 12 a-d The CT images of the Rudki-type double spiral ornament DSO_2 (Kałdus, Poland) (http://oldcopper.org, adapted). The cramped joints are indicated by red arrows

ecumene of the TRB possibly became an important part of metal trading network during the Baden period in Poland.

It is puzzling why the Silesian and Kuyavian centres are missing from the Rudki-type DSO distribution network, since these regions had a leading role in spreading the Baden culture towards the northern ecumene of the TRB (BukowskaGedigowa 1975; Zastawny 2015a, b; Przybył 2009, pp. 123-29; Adamczak et al. 2015a, p. 215). The absence of these 
Fig. 13 The chaîne opératoire implemented during plastic working of the Rudki-type double spiral ornaments from Poland: DSO 2 (a-c; Kałdus) and DSO 7 (d-f; Rudki) (Kowalski et al. 2017, 565, Fig. 10; Scott 1991, 7 8, Figs. 11 and 12, adapted); $\mathbf{a}, \mathbf{b}$, d $\times 100 ; \mathbf{e} \times 200 ; \mathbf{c}$, f $500 \times$. Blue arrowhead, hot forging; red arrowhead, annealing arrowhead, cold forging; orange
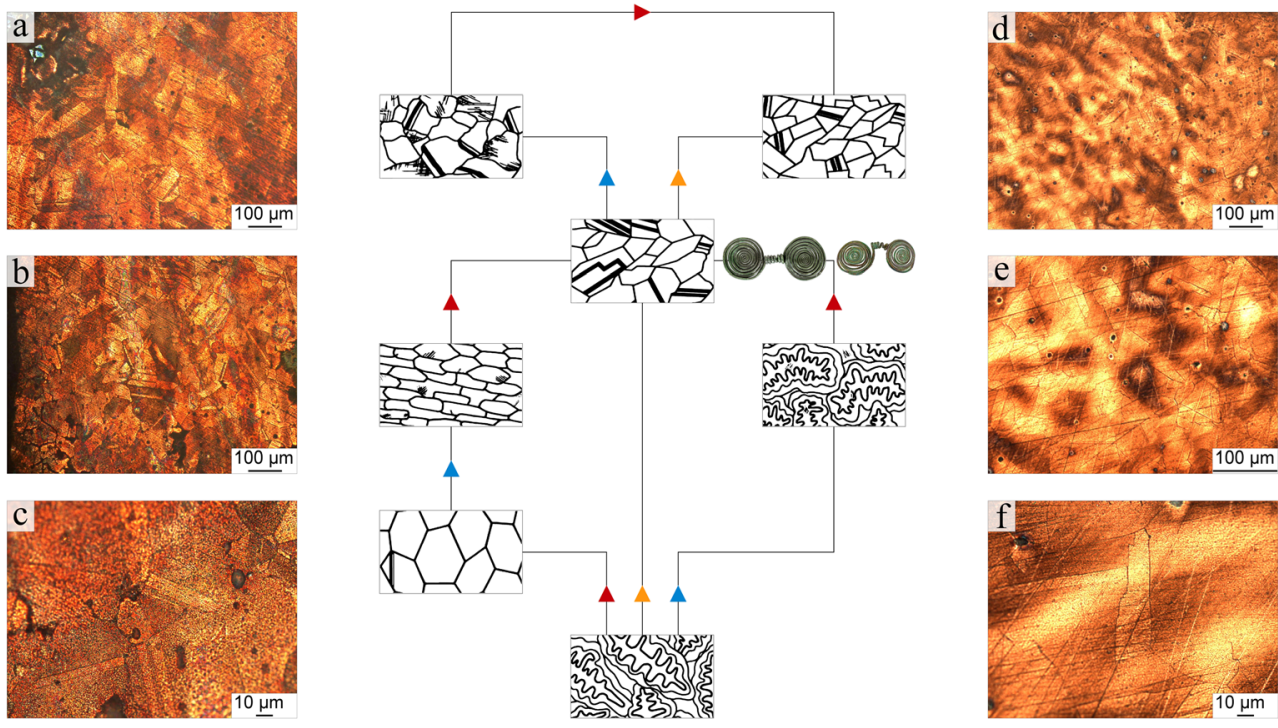

artefacts can partly be understood in terms of promoting by the southern Baden communities the Vistula route and the Carpathian passes (alongside the Oder route and Moravian Gate route) as distributive channels for metal flow (including the DSOs). Perhaps, it would be reasonable to expect that the double spiral ornaments first appeared in the TRB communities from the Sandomierz Upland (Przeuszyn) and from there were further redistributed (and perhaps also socially reinterpreted) to their northern kinsmen from the region of Chełmno (Kałdus) and Greater Poland (Rudki). This hypothesis may be supported by the flint trading route (in particular the axes and retouched blades made from Świeciechów and striped flint) running from the mines in the eastern part of
Lesser Poland towards the northern ecumene of the TRB (see, e.g. Balcer 1988; Sulimirski 1960).

\section{Deposition context and hoarding pattern}

It needs to be stressed that the hoards from Kałdus, Przeuszyn and Rudki were incorporated in the cultural landscape established by the TRB communities near the local leading settlement centres. This is supported also by the famous Eneolithic hoard from Bytyn (with two copper yoked-ox figures) and a flat copper axe from Pamiatkowo that were found near Rudki (Pieczyński 1985; Wierzbicki 2013, pp. 196 and 242).

Fig. 14 The spiral armband from the Rudki hoard (Poland) (by courtesy of the Archaeological Museum in Poznań, Poland). The rod used for coiling the armband was combined with the cramped joints

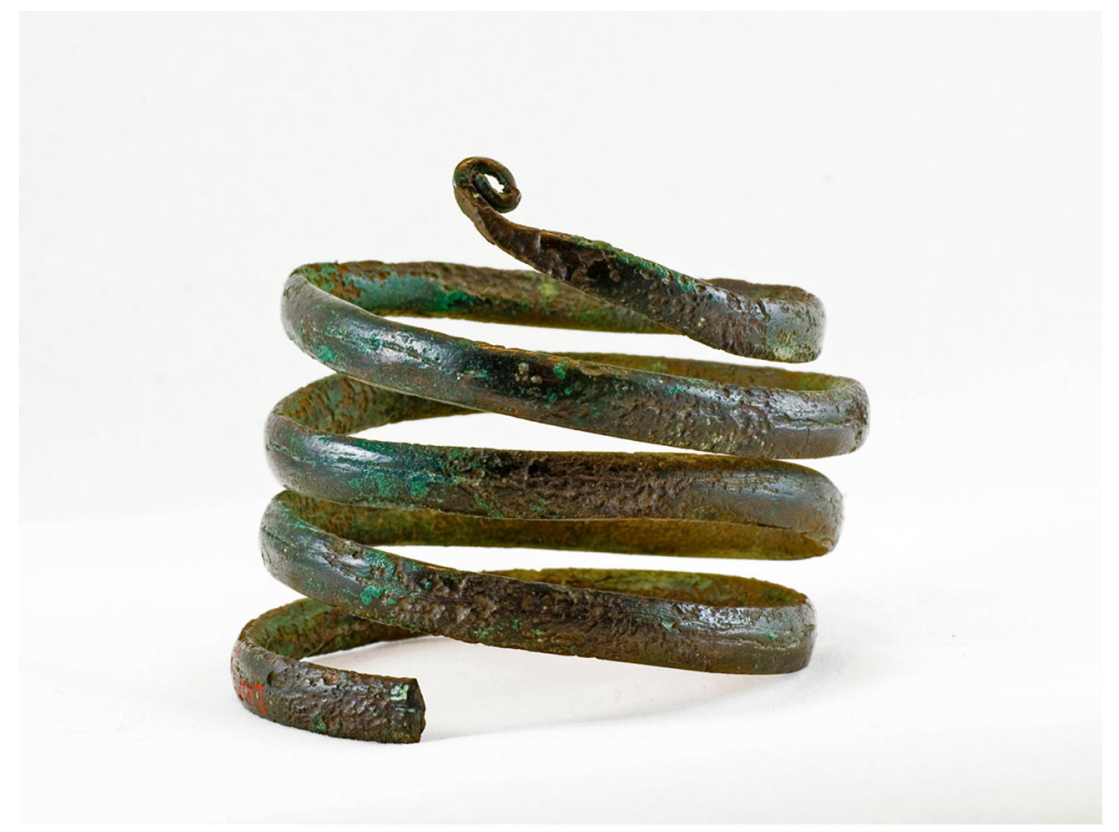


OxCal v 4.3.2 Bronk Ramsey (2017); r.5; IntCal 13 atmospheric curve (Reimer et al. 2013)

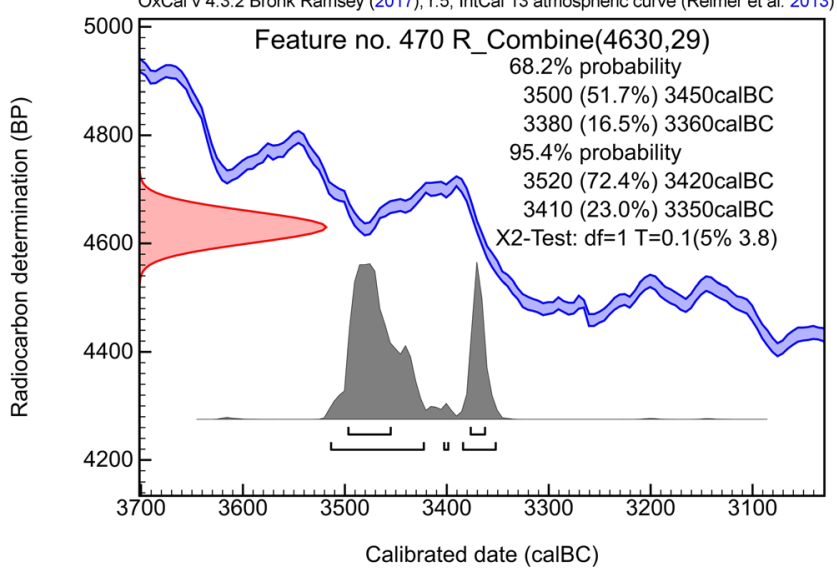

Fig. 15 The combined ${ }^{14} \mathrm{C}$ dates obtained for the Rudki-type double spiral ornament DSO_1 (Kałdus, Poland) (OxCal v. 4.3)

The configuration of the votive offerings found in the Kałdus hoards adds essential information to the insights into the hoarding pattern of the Rudki-type DSO. The DSO 2 was recovered from the ceremonial pit no. 1186 near the northern corner of a pole construction (Adamczak et al. 2015a, pp. 201-3 and 2134, Fig. 3), and it is important to recall that the TRB copper hoard found in Kietrz (southern Poland) was deposited in the corner of a domestic building (Łęczycki 1982, p. 215; 2004, pp. 60-2). There are, therefore, some indications that pit no. 1186 could be intended to serve as a foundation deposit for a ceremonial house. The supporting evidence comes from the arrangement of the remaining features found within the remains of the pole construction and the range of the offerings deposited there. If the concept of a ceremonial house is accepted, a conclusion that the place where DSOs were found could have had a significant impact on stimulating the cooperative ideology within the TRB community in Kałdus seems credible. Also, this might reflect an institutional role of the copper metalwork in the TRB social praxis (see Müller $(2012,2013)$ for opinion about

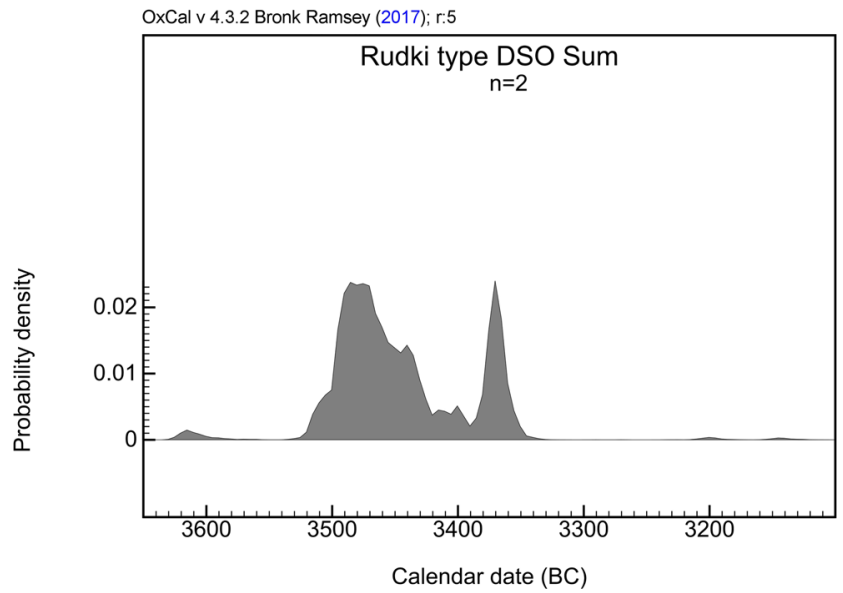

Fig. 16 The sum of probability density estimated for the ${ }^{14} \mathrm{C}$ dates obtained for the Rudki-type double spiral ornaments from Kałdus (Poland) (OxCal v. 4.3)

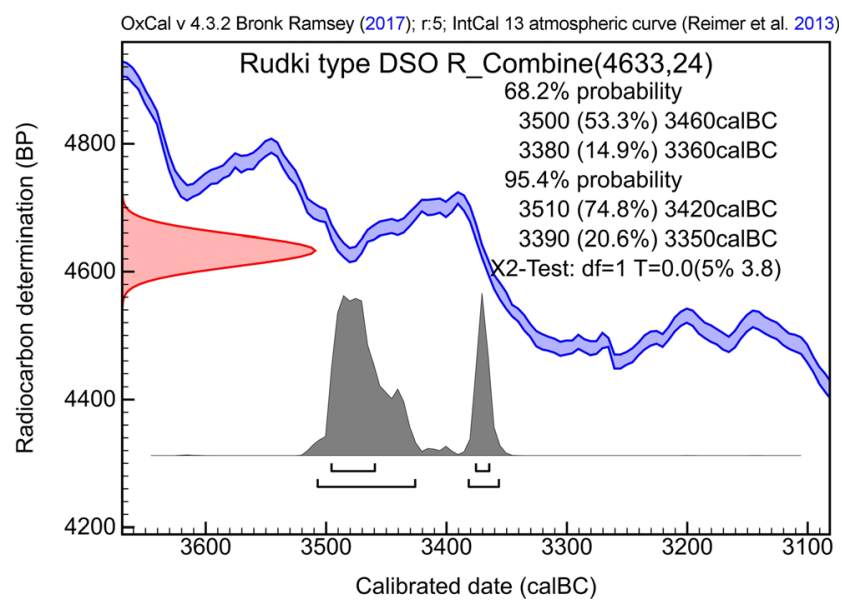

Fig. 17 The combined ${ }^{14} \mathrm{C}$ dates obtained for the Rudki-type double spiral ornaments from Kałdus (Poland) (OxCal v. 4.3)

the impact of copper metalwork on a cooperative mode of organisation in the northern TRB).

One of the distinctive features of the Eneolithic hoards from Kałdus is the votive offering package indicating a hoarding pattern which involved depositing the Rudki-type DSOs together with a neck fragment of the beheaded amphora and a small comb-band-decorated beaker (Fig. 19).

\section{Contextual significance}

The neck fragment of the beheaded amphora from pit no. 1186 in Kałdus may be of importance in the discussion about the contextual significance of the Rudki-type DSO. The basic premise here is the presence of the narrative scene incised on a shoulder of the discussed potsherd, which appears to be decorated with a motif in which two spirals are joined together with a cylindrical link at the centre and suspended by two strings (?) to the base of the neck. Such a motif is repeated four times in the reverse manner. Remarkably, the narrative scene from Kałdus may, in fact, represent a model of a wagon (Fig. 20), referring to, e.g. the ceramic four-wheel wagons from Szigetszentmárton or Budakalász (Hungary) which are dated to the classical Baden period (= 3300-3100 cal BC; Anthony 2007, pp. 68-9, Fig. 4.3; Bondár and Raczky 2009, pp. 98-9, Pl. 79).

Interestingly, the majority of the wagon models linked to the Boleráz tradition $(=3500-3350$ cal BC) have a wagon box with a straight floor without any indication of axles or wheels, such as the one discovered in Radošina (Slovakia). In this context, the similarity of the representation of a wagon from Kałdus to a classic Baden ceramic wagon model may appear as a contradiction between the resulting radiocarbon date $(=3502-$ 3363 cal BC) and the manner in which the axles and the wheels could possibly be portrayed on the amphora from Kałdus (Bondár 2012a, p. 78; 2012b, pp. 43-8).

It is worth to recall that one of the earliest known wagon images preserved on the famous TRB vessel from 


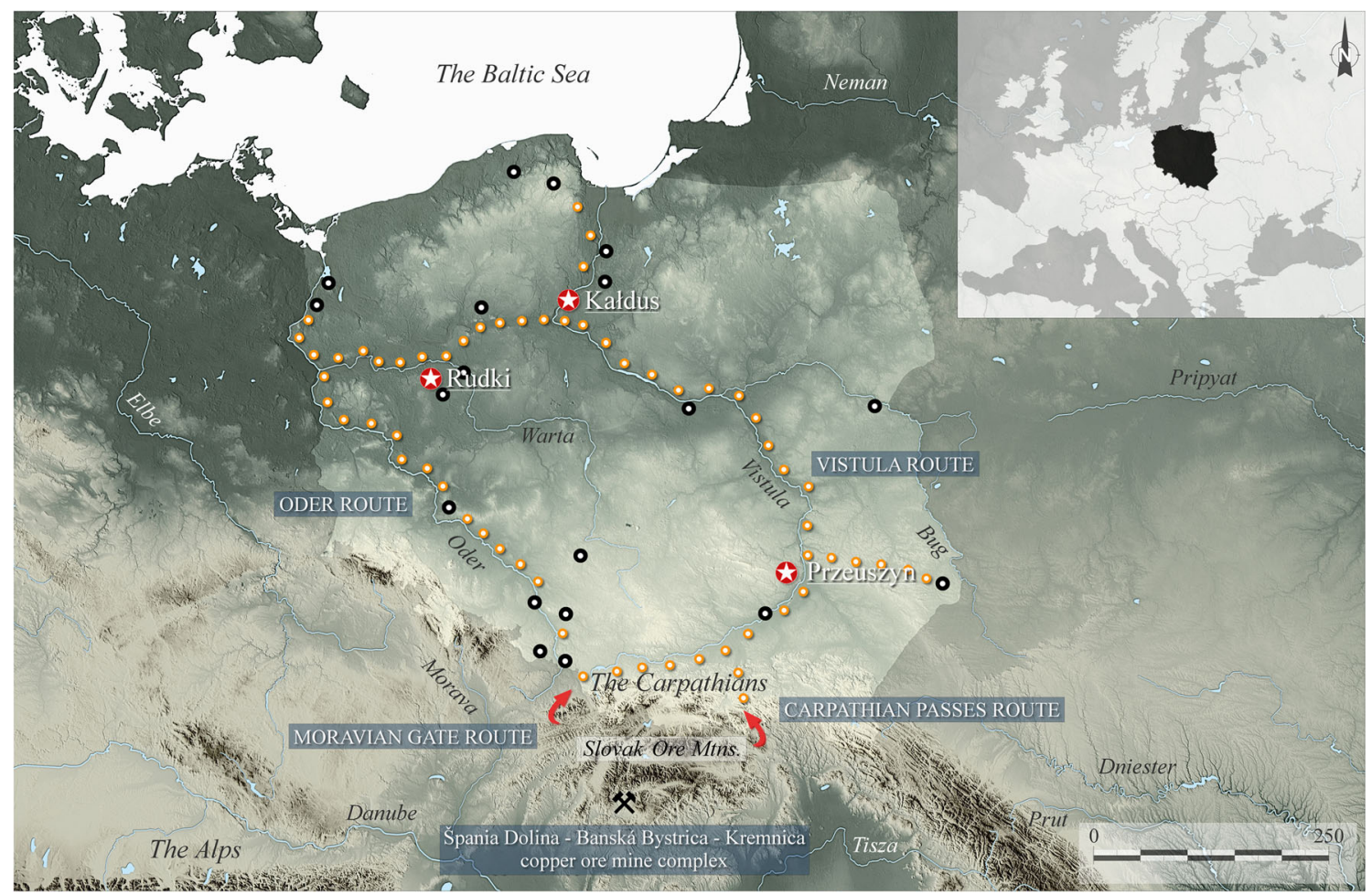

Fig. 18 Distribution of the Rudki-type double spiral ornaments $(7)$ and the Bytyn A axes from Poland (-) against the backdrop of the possible distribution channels for the copper ore mine complex in the Slovak Ore Mountains $(\leftrightarrow)$ and the copper metalwork (re-)distribution network overlapping the TRB ecumene (@) during the TRB-MES III (Adamczak et al. 2015a, 2017; Kostrzewski 1962; Szpunar 1987; map

Bronocice (Poland) is dated to 3635-3370 cal BC (with a $68.2 \%$ probability) (Bakker et al. 1999). Relying on a radiocarbon result of 3420-3385 cal BC (with a $68.2 \%$ probability) from the wagon track remains discovered in Flintbek (Germany) (Mischka 2011, 2013), a 35023363 cal BC date range (with a $68.2 \%$ probability) obtained for the ceremonial pit no. 1186 (see Tables 1 and 5) may justify placing the narrative scene from Kałdus amongst background: Yarr65/Shutterstock.com). It is possible that the ornaments first appeared in the TRB communities from the Sandomierz Upland (Przeuszyn) and from there were further redistributed (and perhaps also socially reinterpreted) to their northern kinsmen from the region of Chełmno (Kałdus) and Greater Poland (Rudki)

the earliest proofs for wheeled transport in the Eneolithic Europe (c.f. Anthony 2007, pp. 65-72; Bondár 2012b).

The importance of the motif incised on the amphora from Kałdus relies not only in the fact that it may represent a model of a wagon, but also in a possibility that it could have been inspired by the shape of the double spiral ornament. This, in turn, may offer a hint about the possible wearing style of the Rudki-type DSO, suggesting the use as a pectoral ornament.
Fig. 19 The hoarding assemblage typical for the Rudki-type double spiral ornaments deposited in the TRB ceremonial pits from Kałdus (Poland). The votive offering package involved (i) the Rudkitype DSO, (ii) neck fragment of the beheaded amphora and (iii) a small comb-band-decorated beaker

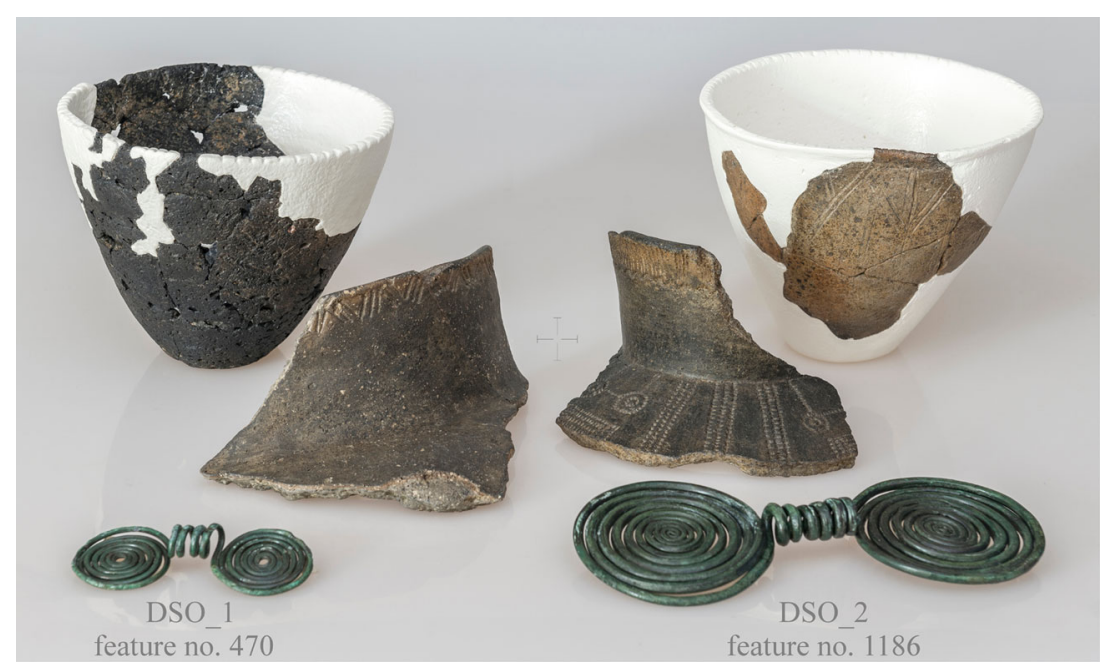


Fig. 20 The contextual significance of the offerings deposited in the TRB ceremonial pit no. 1186 from Kałdus (Poland). The motif incised on the amphora can reflect a symbolic triad where (i) the wagon model and (ii) the double spiral ornament are bonded to each other by (iii) the 'sun archetype' (Anthony 2007, 68-9, Fig. 4.3; Bondár 2012b, 41, Fig. 15; Bondár and Raczky 2009, 98-9, Pl. 79; CLIPAREA 1 Custom media/ Shutterstock.com, adapted)
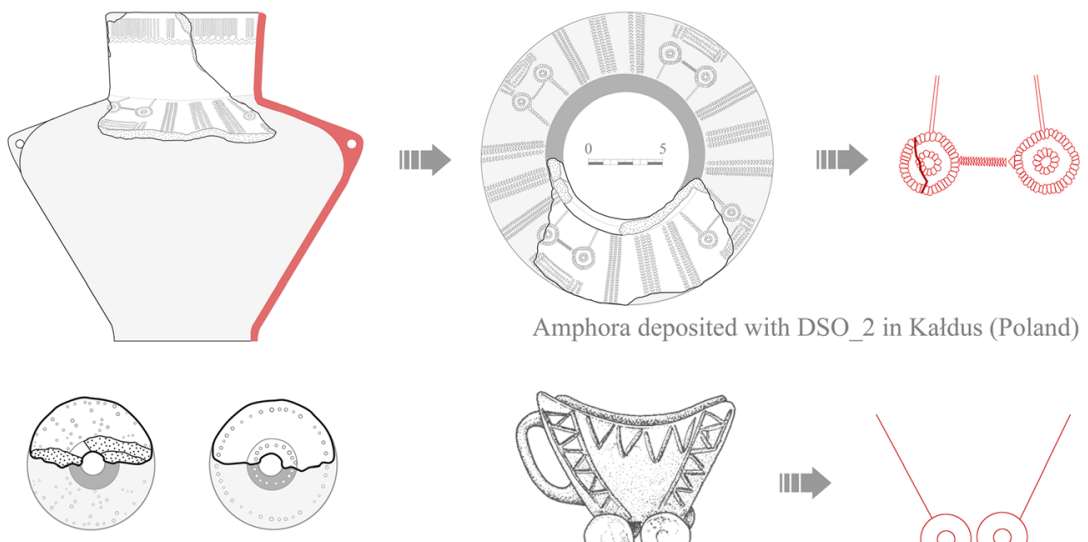

Ceramic spindle whorl deposited with DSO_2 in Kałdus (Poland)
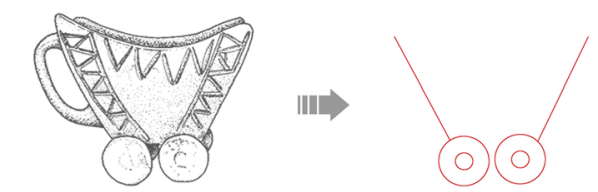

Ceramic wagon model from Szigetszentmárton (Hungary)
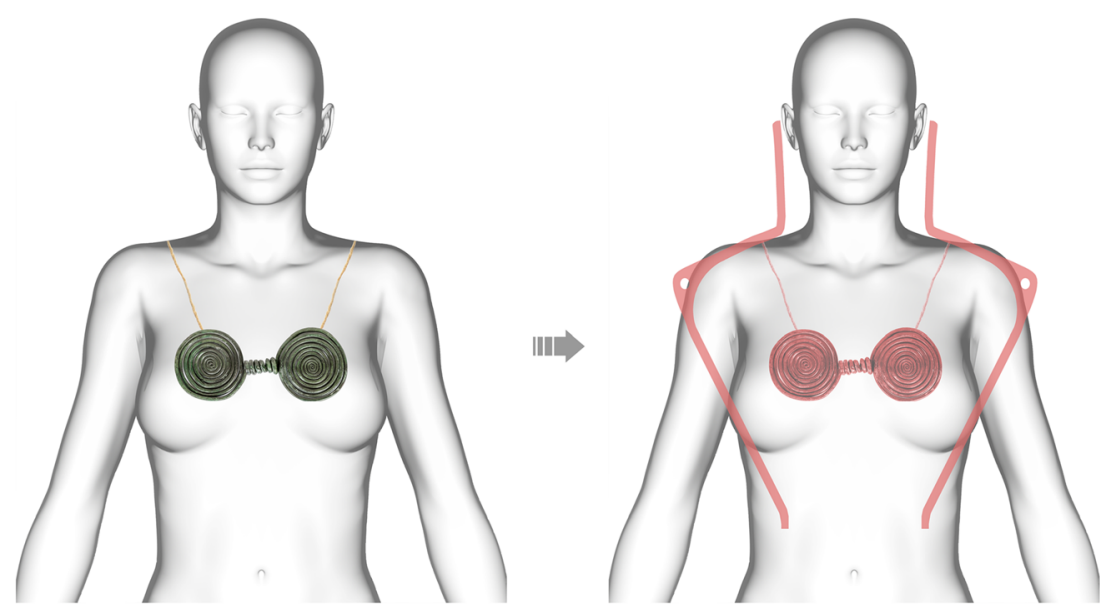

Such a scenario becomes more reliable if one accepts that an amphora was meant to imitate the shape of a female body (Adamczak 2013; see Fig. 20). This is in good correspondence with the cultural phenomenon outlined by Matuschik (2011, pp. 230-4, Abb. 159-61) who claims that a trend of attributing human characteristics to pottery is evident in Central Europe during the Neolithic and Eneolithic periods.

\section{The Baden spiral metalwork package}

Considering the full spectrum of the Baden metalwork over its entire spatial distribution from the TRB-MES III $(=3500-$ 3350 cal BC) onwards, it can be noticed that in the Baden culture complex there was a certain tradition of spiral ornaments. This makes possible to outline the Baden spiral package $^{6}$ which includes the armbands, like those ones found in the hoards from Bygholm (Denmark) or Rudki and Skarbienice (Poland) (Kowalski et al. 2016, p. 196; Pieczyński 1986), and also the so-called Hakenspiralen and

\footnotetext{
${ }^{6}$ The Baden spiral package also includes more fragile jewellery, commonly known as the salta leone (see, e.g. Pieczyński 1986).
}

Brillenspiralen (Matuschik 1996). The results of this research indicate that such a package must be now complemented by the Rudki-type double spiral ornaments (=Doppelspiralen). It needs to be emphasised that the Baden spiral metalwork package found an echo in pottery decoration. The evidence comes from the images incised on the ceramic vessels recovered from Kałdus (= Doppelspiralen; the TRB East Group), Sebeș-Papuc (= Brillenspiralen; Coțofeni culture) and See am Mondsee (= Hakenspiralen; Mondsee culture) (Ciugudean 2000, p. 267, Pl. 141; Matuschik 1996, pp. 9, 12-3, Abb. 3-6; Mayer 1977, Taf. 115 and 116; Popa 2013, pp. 98, 103, Pl. 2 and 7; Roman 1976, p. 143, Pl. 43; Fig. 21).

\section{Final remarks}

The Secondary Products Revolution, a model proposed by Sherratt (1981, 1983, 1986, 2006), can be used to illustrate how the TRB communities from the region of modern Poland entered the Baden complex orbit. The mechanism and dynamics of the cultural processes leading to the closer cooperation and integration between the TRB communities and the Baden 
Fig. 21 The images of the Baden spiral metalwork package incised on pottery (Matuschik 1996, 9, 12, Abb. 3 and 4; Mayer 1977, Taf. 115 and 116; Popa 2013, 103, Pl. 7, adapted)
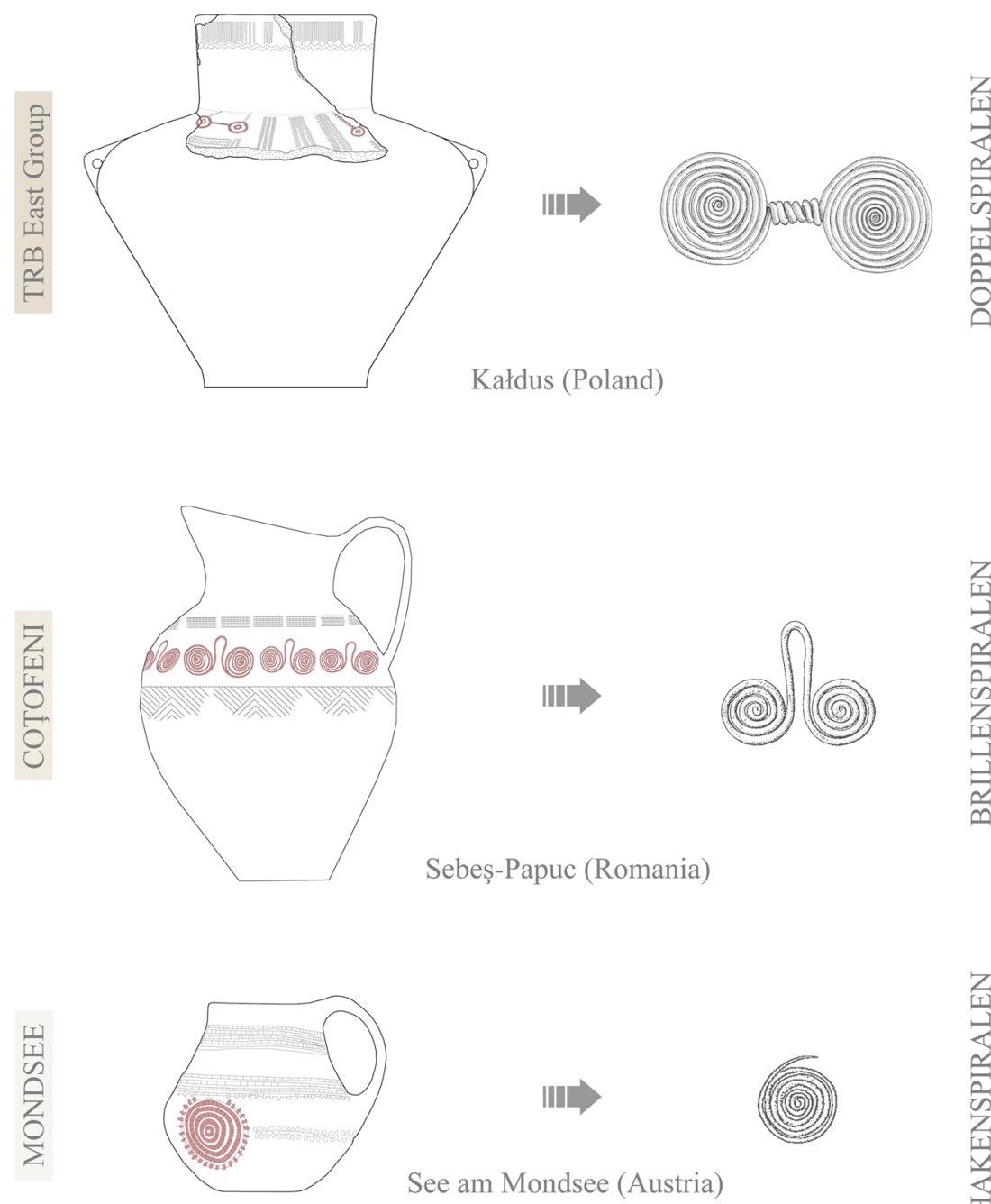

culture milieu were most probably generated by the strong demand for metal goods by the communities from the North European Plain. Indeed, the archaeological data confirm that the emergence of the Baden cultural package over almost the entire TRB ecumene is contemporary with a remarkable consumption of arsenical copper (Adamczak et al. 2015a, p. 215; Garbacz-Klempka et al. 2015; Kienlin 2014, p. 453; Novotná 1977 , p. 628). Contrary to confusing opinions expressed recently about the scale (Nowak 2017, p. 155) or culture-based creativity of the copper metalwork (Przybył 2017), the dynamics of this process appear quite significant. Good examples of these processes are represented by the Bytyn-type flat axes and the copper daggers found in Poland that are reflecting a stable supply of metal to the territory occupied by the TRB (Adamczak et al. 2015a, 2017; see Fig. 18). The wealth of the copper metalwork hoarded in Bytyń, Kietrz or Rudki strongly supports Sherratt's model.

One widely held belief is that the process of expanding the Baden cultural patterns to the TRB milieu was accompanied by the introduction of wheeled transport (Przybył 2015, p. 484, Fig. 9; 2017, Fig. 30A). The evidence comes from the wagon images which were incised on the ceramic vessels from Bronocice, Dopiewo and Kałdus. The radiocarbon dating results make it possible to conclude that the very first indications of such an integration appeared about $3650 \mathrm{cal} \mathrm{BC}$, but it was already at the beginning of 3500 cal BC when this process started to accelerate (c.f. Sochacki 1981).

It is essential to mention that together with the introduction of the Baden metalwork package by the TRB communities in Poland, some foreign religious practices were also absorbed including a new funeral rite allowing cremation of the deceased (recently confirmed also in Kałdus) (Adamczak et al. 2015a, p. 215; Przybył 2015, 2017). Apparently, the inflow of the copper metalwork to the northern peripheries of the Eneolithic Europe was more than merely an entry of metal, but it could also have been a catalyst facilitating the introduction of some new cultural elements to the TRB communities inhabiting the region of modern Poland and leading to the important changes in their identities.

We believe that the results presented here contribute to the breakdown of the stereotypes about the consumption pattern 
of the copper metalwork during the mid-4th millennium $\mathrm{BC}$ in this region and thus stimulate further research and discussion.

Acknowledgments We thank the anonymous reviewers for their careful reading of our manuscript and their many insightful comments and suggestions. This research did not receive any specific grant from funding agencies in the public, commercial, or not-for-profit sectors.

Open Access This article is distributed under the terms of the Creative Commons Attribution 4.0 International License (http:// creativecommons.org/licenses/by/4.0/), which permits unrestricted use, distribution, and reproduction in any medium, provided you give appropriate credit to the original author(s) and the source, provide a link to the Creative Commons license, and indicate if changes were made.

\section{References}

Adamczak K (2013) Communities of the Funnel Beaker culture during the era of erecting monumental tombs in the territory of Poland: rituals, vessels and social divisions. In: Bakker JA, Bloo SBC, Dütting MK (eds) From funeral monuments to household pottery. Current advances in Funnel Beaker culture (TRB/TBK) research. Proceedings of the Borger Meetings 2009, The Netherlands (= BAR International Series 2474). Archaeopress, Oxford, pp 177-193

Adamczak K, Kowalski Ł, Bojarski J, Weinkauf M, Garbacz-Klempka A (2015a) Eneolithic metal objects hoard from Kałdus, Chełmno commune, kujawsko-pomorskie voivodeship. Spraw Archeol 67:199219

Adamczak K, Kowalski Ł, Garbacz-Klempka A, Dobrzański K (2015b) Siekieromłot typu Szendrö z Karłowic Małych, woj. opolskie w świetle analiz archeologicznych i metaloznawczych. Śl Spraw Archeol 57:81-92

Adamczak K, Samborski M, Garbacz-Klempka A, Bednarz S, Kowalski $Ł$ (2017) Pierwsze znalezisko eneolitycznej siekiery miedzianej na Mazowszu. Acta Archaeol Lodz 63:83-92. https://doi.org/10. 26485/AAL/2017/63/7

Anthony DW (2007) The Horse, the Wheel, and Language: How BronzeAge Riders from the Eurasian Steppes Shaped the Modern World. Princeton University Press, Princeton

Bakker J, Kruk J, Lanting A, Milisauskas S (1999) The earliest evidence of wheeled vehicles in Europe and the Near East. Antiquity 73(282): 778-790. https://doi.org/10.1017/S0003598X00065522

Balcer B (1988) The Neolithic flint industries in the Vistula and Odra basins. Prz Archeol 35:49-100

Bondár M (2012a) A new Late Copper Age wagon model from the Carpathian Basin. In: Anreiter P, Bánffy E, Bartosiewicz L, Meid W, Metzner-Nebelsic C (eds) Archaeological, cultural and linguistic heritage: Festschrift for Erzsébet Jerem in Honour of Her 70th Birthday (= Archaeolingua Series Maior 25). Archaeolingua, Budapest, pp 79-92

Bondár M (2012b) Prehistoric wagon models in the Carpathian Basin (3500-1500 BC) (= Archaeolingua Series Minor 32). Archaeolingua, Budapest

Bondár M, Raczky P (2009) The Copper Age cemetery of Budakalász. Pytheas, Budapest

Bronk Ramsey C (2009) Dealing with outliers and offsets in radiocarbon dating. Radiocarbon 51(3):1023-1045. https://doi.org/10.1017/ S0033822200034093

Bronk Ramsey C (2017) Methods for summarising radiocarbon datasets. Radiocarbon 59(2):1809-1833. https://doi.org/10.1017/RDC.2017. 108
Bronk Ramsey C, Lee S (2013) Recent and planned developments of the program OxCal. Radiocarbon 55(2-3):720-730. https://doi.org/10. 1017/S0033822200057878

Bronk Ramsey C, Dee M, Lee S, Nakagawa T, Staff RA (2010) Developments in the calibration and the modeling of radiocarbon dates. Radiocarbon 52(2-3):953-961. https://doi.org/10.1017/ S0033822200046063

Bukowska-Gedigowa J (1975) Kultura pucharów lejkowatych w dorzeczu Górnej Odry. Prz Archeol 23:83-186

Ciugudean H (2000) Eneoliticul final în Transilvania şi Banat: cultura Coțofeni (= Bibliotheca Historica et Archaeologica Banatica 26). Editura Mirton, Timişoara

Cook SRB, Aschenbrenner S (1975) The occurrence of metallic iron in ancient copper. J Field Archaeol 2(3):251-266

De Boer DKG, Borstrok JJM, Leenaers AJG, Van Sprang HA, Brouwer PN (1993) How accurate is the fundamental parameter approach? XRF analysis of bulk and multilayer samples. X-Ray Spectrom 22: 33-38

De Muynck D, Cloquet C, Vanhaecke F (2008) Development of a new method for $\mathrm{Pb}$ isotopic analysis of archaeological artefacts using single-collector ICP-dynamic reaction cell-MS. J Anal Atom Spectrom 23:62-71

Elam WT, Shen RB, Scruggs B, Nicolosi J (2004) Accuracy of standardless FP analysis of bulk and thin film samples using a new atomic database. Adv X-ray Anal 47:104-109

Frank C, Pernicka E (2012) Copper artifacts of the Mondsee group and their possible sources. In: Midgley MS, Sanders J (eds) Lake Dwellings after Robert Munro, Proceedings from the Munro International Seminar: the lake dwellings of Europe 22nd and 23rd October 2010. University of Edinburgh. Sidestone Press, Leiden, pp $113-138$

Furholt M (2009) Die nördlichen Badener Keramikstile im Kontext des mitteleuropäischen Spätneolithikums /3650-2900 v.Chr. (= Studien zur Archäologie in Ostmitteleuropa 3). Dr. Rudolf Habelt GmbH, Bonn

Galer SJG, Abouchami W (1998) Practical application of lead triple spiking for correction of instrument mass discrimination. Mineral Mag 62:491-492

Garbacz-Klempka A, Kozana J, Piękoś M, Cieślak W, Perek-Nowak M, Kowalski Ł, Adamczak K, Łoś J (2015) Copper and arsenical copper during Eneolithic in metallographic and mechanical properties examination. Arch Foundry Eng 15(4):23-28

Gedl M (2004) Die Fibeln in Polen (= Prähistorische Bronzefunde XIV: 10). Franz Steiner Verlag, Stuttgart

Goslar T (2018) Description of procedures of AMS 14C dating used in the Poznań Radiocarbon Laboratory. Accessed 03.10.18. http:// radiocarbon.pl/images/formularze/procedure ams prl.doc

Horváthová E, Zastawny A (2016) Rádiouhlíkové datovanie d’alších lokalít badenskej kultúry z územia Slovenska. Archeol Středni Čechy 20:959-966

Junghans S, Sangmeister E, Schröder M (1974) Kupfer und Bronze in der frühen Metallzeit Europas. Studien zu den Anfängen der Metallurgie. Mann, Berlin

Kadar M (2002) Chemical composition of prehistoric copper artefacts from Transylvania, Romania. Institute of Archaeo-Metallurgical. Studies 22:11-14

Kasiński W (1936) Skarb miedziany z Przeuszyna w pow. opatowskim. Z Otchłani Wieków 11:141

Ketterer ME, Peters MJ, Tisdale PJ (1991) Verification of a correction procedure for measurement of lead isotope ratios by inductively coupled plasma mass spectrometry. J Anal Atom Spectrom 6:439443

Kienlin TL (2011) Aspects of the development of casting and forging techniques from the Copper Age to the Early Bronze Age of Eastern Central Europe and the Carpathian Basin. In: Yalc Ü (ed) 
Anatolian metal V (= Montanhistorische Zeitschrift. Der Anschnitt 24). Deutsches Bergbau-Museum, Bochum, pp 127-136

Kienlin TL (2014) Aspects of metalworking and society from the Black Sea to the Baltic Sea from the fifth to the second millennium BC. In: Roberts BW, Thornton CP (eds) Archaeometallurgy in global perspective. Springer, New York, pp 447-472

Koehler K (1900) Album zabytków przedhistorycznych Wielkiego Ksiestwa Poznańskiego zebranych w Muzeum Towarzystwa Przyjaciół Nauk w Poznaniu 2. Wydawnictwo Przyjaciół Nauk, Poznań

Kostrzewski J (1924) Z badań nad osadnictwem wczesnej i środkowej epoki bronzowej na ziemiach polskich. Prz Archeol 2:161-218

Kostrzewski J (1953) Wytwórczość metalurgiczna w Polsce od neolitu do wczesnego okresu żelaznego. Prz Archeol 9:177-213

Kostrzewski J (1962) Skarby i luźne znaleziska metalowe od eneolitu do wczesnego okresu żelaza z górnego i środkowego dorzecza Wisły i górnego dorzecza Warty. Prz Archeol 15:5-133

Kowalski Ł, Krzyszowski A, Adamczak K, Garbacz-Klempka A (2016) Wyniki badań archeometalurgicznych tzw. siekiery z dawnej miejscowości Antoniny, pow. Chodzieski. Fontes Archaeol Posn 52:175-205

Kowalski Ł, Garbacz-Klempka A, Dobrzański K (2017) The WrocławSzczytniki flanged axe from Koperniki A contribution to archaeometallurgical studies on the Únětice axes in Poland. Archeol Rozhl 69(4):555-582

Krause R (2003) Studien zur kupfer -und frühbronzezeitlichen Metallurgie zwischen Karpatenbecken und Ostsee. Verlag Marie Leidorf $\mathrm{GmbH}$, Rahden/Westf

Łęczycki S (1982) Kietrz, woj. Opole, stanowisko D. Silesia Antiqua 24: 213-217

Łęczycki S (2004) Kietrz, Bytyń, Szczecin-Śmierdnica. Einige Anmerkungen zur Kulturzugehörigkeit des Hortesfundes von Bytyń / Kietrz, Bytyń, Szczecin-Śmierdnica. Rozważania na temat przynależności kulturowej skarbu z Bytynia. Spraw Archeol 56:3377

Ling J, Stos-Gale Z, Grandin L, Billström K, Hjärthner-Holdar E, Persson P-O (2014) Moving metals II: provenancing Scandinavian Bronze Age artefacts by lead isotope and elemental analyses. J Archaeol Sci 41:106-132

Lissauer A (1891) Alterthümer der Bronzezeit in der Provinz Westpreussen und den angrenzenden Gebieten (= Abhandlung zur Landeskunde der Provinz Westpreussen Heft II). Kommissions Verlag von Th. Bertling, Danzig

Lutz J, Pernicka E (1996) Energy dispersive X-ray fluorescence analysis of ancient copper alloys: empirical values for precision and accuracy. Archaeometry 38(2):313-323

Mantler M, Kawahara N (2004) How accurate are modern fundamental parameter methods? Rigaku J 21:17-25

Matuschik I (1996) Brillen- und Hakenspiralen der frühen Metallzeit Europas. Germania 74:1-43

Matuschik I (2011) Siedlungsarchäologie im Alpenvorland XII: Die Keramikfunde von Hornstaad-Hornle I-VI. Besiedlungsgeschichte der Fundstelle und Keramikentwicklung im beginnenden 4 . Jahrtausend v. Chr. im Bodenseeraum (= Forschungen und Berichte zur Vor- und Frühgeschichte in Baden-Württemberg, Band 122). Kommissionsverlag Konrad Theiss Verlag, Stuttgart

Mayer EF (1977) Die Äxte und Beile in Österreich (= Prähistorische Bronzefunde IX: 9). C.H. Beck'sche Verlag, München

Mischka D (2011) The Neolithic burial sequence at Flintbek LA 3, north Germany, and its cart tracks: a precise chronology. Antiquity 85(329):742-758. https://doi.org/10.1017/S0003598X00068289

Mischka D (2013) Die neolithische Besiedlungsgeschichte im Raum Flintbek und die Bedeutung der Wagenspuren vor dem Hintergrund neuer Datierungen. In: Kadrow S, Włodarczak P (eds) Environment and subsistence-forty years after Janusz Kruk's
„Settlement studies..." (= Studien zur Archäologie in Ostmitteleuropa 11). Dr. Rudolf Habelt GmbH, Bonn, pp 117-138

Modarressi-Tehrani D, Garner J (2015) New approaches on mining activities in the Slovakian Ore Mountains. In: Argenti Fodina 2014 (= Zborník Prednášok z medzinárodnej konferencie Argenti fodina 2014, ktorá sa konala $\mathrm{v}$ dňoch 10.-12. Septembra 2014). Slovenské Banské múzeum, Banska Štiavnica, pp 45-57

Müller J (2012) Aspenstedt-Großer Berg: Ein spätneolithisches Grab mit kupfernem Nietdolch - Hinweis auf eine "verpasste" Innovation. Praehist Z 87(1):44-57. https://doi.org/10.1515/pz-2012-0003

Müller J (2013) Missed innovation: the earliest copper daggers in Northern Central Europe and Southern Scandinavia. In: Bergerbrant S, Sabatini S (eds) Essays in archaeology and heritage studies in honour of Professor Kristian Kristiansen. Oxbow, Oxford, pp 443-448

Müller J, Brozio JP, Demnick D, Dibbern H, Fritsch B, Furholt M, Hage F, Hinz M, Lorenz L, Mischka D, Rinne C (2012) Periodisierung der Trichterbecher-Gesellschaften. Ein Arbeitsentwurf. In: Hinz M, Müller J (eds) Siedlung Grabenwerk Großsteingrab. Studien zu Gesellschaft, Wirtschaft und Umwelt der Trichterbechergruppen im nördlichen Mitteleuropa (= Frühe Monumentalität und soziale Differenzierung 2). Dr. Rudolf Habelt GmbH, Bonn, pp 29-33

Novotná M (1977) Neznáme nálezy medenej industrie zo Slovenska. Archeol Rozhl 29:622-633

Nowak M (2017) Ubiquitous settlers, consequent farmers, and monument builders. In: Urbańczyk P, Włodarczak P (eds) The past societies: Polish lands from the first evidence of human presence to the early middle ages. Vol. 2: 5500-2000 BC. IAiE PAN, Warszawa, pp 125170

O'Brien W (2015) Prehistoric copper mining in Europe. 5500-500 BC. Oxford University Press, Oxford

Pieczyński Z (1985) Uwagi o skarbie miedzianym z Bytynia, woj. poznańskie. Fontes Archaeol Posn 34:1-7

Pieczyński Z (1986) Skarb miedziany ze Skarbienic, woj. bydgoskie. Fontes Archaeol Posn 35:35-40

Popa CI (2013) Motive-simbol pe vasele ceramice Coțofeni: cercuri concentrice, spirale, spirale-ochelari, Terra Sebus. Acta Mus Sabes $5: 77-110$

Przybył A (2009) Społeczności późnoneolitycznej kultury pucharów lejkowatych na Kujawach. Problem wpływów z kręgu kultury badeńskiej. Wydawnictwo Poznańskie, Poznań

Przybył A (2015) The Baden complex and the Funnel Beaker Culture in the Polish lowlands. The problem of "Lowland Badenization". In: Nowak M, Zastawny A (eds) The Baden culture around the Western Carpathians (= Via Archaeologica. Źródła z badań wykopaliskowych na trasie autostrady A4 w Małopolsce). Krakowski Zespół do Badań Autostrad, Kraków, pp 471-494

Przybył A (2017) From south to north. Baden culture people and their neighbours. In: Urbańczyk P, Włodarczak P (eds) The past societies: Polish lands from the first evidence of human presence to the Early Middle Ages. Vol. 2: 5500-2000 BC. IAiE PAN, Warszawa, pp 171-209

Rademakers FW, Nikis N, De Putter T, Degryse P (2018a) Copper production and trade in the Niari Basin (Republic of Congo) during the $13^{\text {th }}$ to $19^{\text {th }}$ century CE: chemical and lead isotope characterisation. Archaeometry. https://doi.org/10.1111/arcm.12377

Rademakers FW, Verly G, Delvaux L, Degryse P (2018b) Copper for the afterlife in pre Dynastic to Old Kingdom Egypt: provenance characterization by chemical and lead isotope analysis (RMAH collection, Belgium). J Archaeol Sci 96:175-190

Reimer PJ, Bard E, Bayliss A, Beck JW, Blackwell PG, Bronk Ramsey C, Grootes PM, Guilderson TP, Haflidason H, Hajdas I, Hattè C, Heaton TJ, Hoffmann DL, Hogg AG, Hughen KA, Kaiser KF, Kromer B, Manning SW, Niu M, Reimer RW, Richards DA, Scott EM, Southon JR, Staff RA, Turney CSM, van der Plicht J (2013) IntCal13 and Marine13 radiocarbon age calibration curves 0-50,000 
years cal BP. Radiocarbon 55(4):1869-1887. https://doi.org/10. 2458/azu js rc.55.16947

Roman PI (1976) Cultura Coțofeni (= Biblioteca de Arheologie 26). Editura Academiei Republicii Socialiste România, Bucharest

Schreiner M (2007) Erzlagerstätten im Hrontal, Slowakei: Genese und prähistorische Nutzung (= Forschungen zur Archäometrie und Altertumswissenschaft, Band 3). Verlag Marie Leidorf Gmbh., Rahden/Westf

Schreiner M, Heyd V, Pernicka E (2012) Kupferzeitliches Metall in der Westslowakei. In: Kujovský R, Mitáš V (eds) Václav Furmánkek a doba bronzová. Zborník k sedemdesiatym narodeninám (= Archaeologica Slovaca Monographiae - Communicationes 13). Archeologicky ústav Slovenskej akadémie vied, Nitra, pp 355-366

Schwartz FLW (1881) Materialien zu einer prähistorischen Karte der Provinz Posen. Nachtrag III. Beilage zum Programm des Königlichen Friedrich Wilhelms Gymnasium zu Posen. Hofbushdruckerei von W. Decker \& Comp., Posen

Scott DA (1991) Metallography and microstructure of ancient and historic metals. The Getty Conservation Institute, The J. Paul Getty Museum, Los Angeles

Scott ME, Cook GT, Naysmith P (2007) Error and uncertainty in radiocarbon dates. Radiocarbon 49(2):427-440. https://doi.org/10.1017/ S003382220004235

Seger H (1907) Depotfunde aus der Bronze- und Hallstattzeit. In: Masner K, Seger H (eds) Schlesiens Vorzeit in Bild und Schrift. Zeitschrift des Schlesischen Altertumsvereins. Neue Folge. Jahrbuch des schlesischen Museums für Kunstgewerbe und Altertümer. Band 4. Druck von Grass, Barth \& Comp. (W. Friedrich), Breslau, pp 9-43

Sherratt A (1981) Plough and pastoralism: aspects of the secondary product revolution. In: Hodder I, Isaac G, Hammond N (eds) Pattern of the past: studies in honour of David Clarke. Cambridge University Press, Cambridge, pp 261-305

Sherratt A (1983) The secondary exploitation of animals in the Old World. World Archaeol 15:90-104

Sherratt A (1986) Wool, wheels and ploughmarks: local developments or outside introductions in Neolithic Europe? Bull Inst Archaeol 23:115

Sherratt A (2006) La traction animale et la transformation de l'Europe néolithique. In: Pétrequin P, Arbogast RM, Pétrequin AM, van Willigen S, Bailly M (eds) Premiers chariots, premiers araires. La diffusion de la traction animale en Europe pendant les IVe et IIIe millénaires avant notre ère (= CRA Monograph 29). CNRS, Paris, pp 329-360

Sitko R (2007) Influence of X-ray tube spectral distribution on uncertainty of calculated fluorescent radiation intensity. Spectrochim Acta B 62:777-786

Sitko R (2008) Study on the influence of X-ray tube spectral distribution on the analysis of bulk samples and thin films: fundamental parameters method and theoretical coefficient algorithms. Spectrochim Acta B 63:1297-1302

Sitko R, Zawisza B (2012) Quantification in X-ray fluorescence spectrometry. In: Sharma SK (ed) X-ray spectroscopy. IntechOpen, Rijeka, pp 137-162. https://doi.org/10.5772/29367

Sochacki Z (1981) The Baden culture. Archaeol Pol 20:27-63

Stos ZA (2009) Across the wine dark seas ... sailor tinkers and royal cargoes in the Late Bronze Age eastern Mediterranean. In: Shortland AJ, Freestone IC, Rehren T (eds) From mine to microscopeadvances in the study of ancient technology. Oxbow Books, Oxford, pp 163-180

Stos-Gale ZA, Gale NH (2009) Metal provenancing using isotopes and the Oxford archaeological lead isotope database (OXALID). Archaeol Anthropol Sci 1(3):195-213

Struhár V, Soják M, Cheben I (2015) The Baden culture hilltop settlements in Northern Slovakia and their "socio-symbolic" importance. In: Nowak M, Zastawny A (eds) The Baden culture around the Western Carpathians (= Via Archaeologica. Źródła z badań wykopaliskowych na trasie autostrady A4 w Małopolsce). Krakowski Zespół do Badań Autostrad, Kraków, pp 275-310

Suchy JS, Garbacz-Klempka A, Adamczak K, Kowalski Ł, Kozana J, Perek-Nowak M, Szucki M, Piękoś M (2016) Metallographic studies of selected Eneolithic and Bronze Age artifacts from Poland. Key Eng Mater 682:151-159. https://doi.org/10.4028/www.scientific. net/KEM.682.151

Sulimirski T (1960) Remarks concerning the distribution of some varieties of flint in Poland. Światowid 23:281-307

Szpunar A (1987) Die Beile in Polen I (Flachbeile, Randleistebeile, Randleistemeißel) (= Prähistorische Bronzefunde IX: 16). C.H. Beck'sche Verlagsbuchhandlung, München

The University of Texas in Austin (2017) Quadrupole ICP-MS Lab. Limitations 8. Accessed 02.10.17. http://www.jsg.utexas.edu/icp$\mathrm{ms} / \mathrm{icp}-\mathrm{ms} /$

Točik A, Žebrak P (1989) Ausgrabungen in Špania Dolina-Piesky. Zum Problem des urzeitlichen Kupfererzbergbaues in der Slowakei. In: Hauptmann A, Pernicka E, Wagner GA (eds) Archäometallurgie der Alten Welt: Beiträge zum Internationalen Symposium "Old World archaeometallurgy", Heidelberg 1987, Deutsches BergbauMuseum, Bochum, pp 71-78

Truhelka Ć (1895) Prähistorische Bronzen aus dem Bezirke Prozor. In: Hoernes M (ed) Wissenschaftliche Mitteilungen aus Bosnien und der Hercegowina 3. Bosnisch-Herzepowinischen Landesmuseum in Sarajevo, Vienna, pp 510-512

Walder AJ, Platzner I, Freedman PA (1993) Isotope ratio measurement of lead, neodymium and neodymium-samarium mixtures, hafnium and hafnium-lutetium mixtures with a double focusing multiple collector inductively coupled plasma mass spectrometer. J Anal Atom Spectrom 8:19-23

Wierzbicki J (2013) Wielka kolonizacja. Społeczności kultury pucharów lejkowatych w dorzeczu środkowej Warty. SNAP, Poznań

Wilk S (2016) New data about chronology of the impact of the Hunyadihalom-Lažňany horizon on Younger Danubian cultures north of the Carpathian Mountains. Rech Archéol Nouvelle Ser 7: $7-28$

Zastawny A (2015a) The Baden complex in Lesser Poland - horizons of cultural influences. In: Nowak M, Zastawny A (eds) The Baden culture around the Western Carpathians (= Via Archaeologica. Źródła z badań wykopaliskowych na trasie autostrady A4 w Małopolsce). Krakowski Zespół do Badań Autostrad, Kraków, pp $119-150$

Zastawny A (2015b) Absolute chronology of the Baden culture in Lesser Poland - new radiocarbon dates. In: Nowak M, Zastawny A (eds) The Baden culture around the Western Carpathians (= Via Archaeologica. Źródła z badań wykopaliskowych na trasie autostrady A4 w Małopolsce). Krakowski Zespół do Badań Autostrad, Kraków, pp 191-219

Zastawny A, Horváthová E (2017) Kultura badeńska pomiędzy dorzeczem górnej Wisły a północnym Pocisiem. Polsko-słowacki projekt badań transkarpackich relacji kulturowych. In: Gancarski J (ed) Stan i potrzeby badań archeologicznych w Karpatach. Muzeum Podkarpackie, Ruthenus, Krosno, pp 245-268

Žebrák P (1995) The traces of the primary mining of non-ferrous metals in Slovakia. In: Petrović P, Đurđekanović S (eds) Ancient mining and metallurgy in southeast Europe: international symposium, Donji Milanovac, May 20-25, 1990. Museum of Mining and Metallurgy, Bor, pp 13-19

Publisher's note Springer Nature remains neutral with regard to jurisdictional claims in published maps and institutional affiliations. 